\title{
Sınai Mülkiyet Kanunu Madde 85/3 Hükmü Kapsamında Bolar İstisnasının Uygulanması
}

\author{
Barış Kaya* *
}

Öz

İlaç patenti alanında bir yandan bilimsel gelişimin sağlanması, diğer yandan ise, kamunun ilaca erişimi arasında hassas bir dengenin kurulması gerekmektedir. Patentten doğan korumanın kapsamı SMK uyarınca en başta istemlerle belirlenir. Patent hakkı eşdeğerleri de kapsadığından yüksek maliyetli araştırma geliştirme faaliyetinin söz konusu olduğu ilaç piyasasında istemlerin tartş̧masız bir şekilde düzenlemesi gerekir. SMK m. 85/3 hükmünde patent hakkını ihlal etmeyeceği düzenlenen ticari ve sınai amaç taşımayan özel maksatlı fiiller, deneme amaçlı fiiller ve reçete üzerine ilaç hazırlanması temelde, ortak özellik olarak ticari amaç taşımayan, daha ziyade bireysel ihtiyaç ve istifadenin söz konusu olduğu fillerdir. Aynı hükümde düzenlenen ve Bolar istisnası olarak da anılan ilaçların ruhsatlandırılması ve bunun için gerekli test ve deneyleri de içeren deneme amaçı ı filler ise, özellikle ilaç patenti alanı açısından kritik bir öneme sahiptir. Bu istisna sayesinde, eşdeğer ilaç firmaları orijinal ilacın patent süresi içerisinde ruhsat alabilmek amacıyla gerekli test ve deneyleri yapabilmekte, böylelikle patent süresinin bitimini takiben derhal piyasaya girerek rekabetçi ortamı sağlayabilmektedirler. Bolar istisnasının veri imtiyazına uygulanması sayesinde ise, eşdeğer ilaç firmalarının orijinal ilaca ilişkin verilere dayanarak kısaltılmış başvuruda bulunma, bu sayede zorlu ve uzun zaman alacak ruhsat süreci engelini aşmaları söz konusu olmaktadır.

\section{Anahtar Kelimeler}

İlaç patenti • İstemler • Eşdeğer ilaç • Bolar istisnası • Veri imtiyazı

\section{Application of Bolar Exemption Under The Scope of Article 85/3 of The Industrial Property Law}

\begin{abstract}
In the field of pharmaceutical patent there must be a fair balance between scientific developments and the public interest to access (new) pharmaceuticals. In accordance to Industrial Property Law (IPL), the scope of patent prevention shall primarily be determined by the claims of the applicant. As high-budget research and development activities occur in pharmaceutical industry and by taking into account that the patent right includes the rights on generics, the claims on patent must be clearly defined. Activities listed under article 85/3 of IPL and exempted from patent prevention are consisted of acts undertaken privately for non-commercial purposes, acts undertaken for experimental purposes and preparation of medicine in accordance with medical prescription which have non-commercial nature and are undertaken for personal needs and purposes. Experimental acts listed under the said provision including those undertaken for obtaining pharmaceutical authorization and other related tests and trials are also classified as Bolar exemption and have critical importance in the area of pharmaceutical patent. As a result of this exemption generic pharmaceutical companies can execute the required trials and experiments for authorization, thus immediately after the expiration of patent term, they can participate in the market which may bring about a competitive medium. In addition the application of Bolar exemption to data exclusivity enables generic pharmaceutical companies to file abbreviated application for authorization by depending on the data of the original pharmaceuticals which will result in accomplishment of the difficult and long-term authorization process.
\end{abstract}

\section{Keywords}

Pharmaceutical patent $\bullet$ Claims $\bullet$ Generic pharmaceutical $\bullet$ Bolar exemption • Data exclusivity

\footnotetext{
* Sorumlu Yazar: Barış Kaya (Dr.- Avukat), i̇stanbul Barosu, i̇stanbul, Türkiye. Eposta: bariskaya@hotmail.co.uk

Atrf: Kaya, Barış, "Sınai Mülkiyet Kanunu Madde 85/3 Hükmü Kapsamında Bolar i̇stisnasının Uygulanması", İstanbul Hukuk Mecmuası, 76/2, 2018, 417-442. https://doi.org/10.26650/mecmua.2018.76.2.0014
} 


\section{Extended Summary}

In the field of pharmaceutical patent there must be a fair balance between scientific developments and the public interest to access (new) pharmaceuticals. On one hand access to pharmaceuticals is directly related with public health and on the other, as a consequence of pharmaceutical researches, improvements occur both in the field of medical treatment and public health. Thus, the nature of pharmaceutical patent differs from product and process patents related to other fields of industry and includes some special characteristics. As a result, it is important to research both the general patent laws and special regulations concerning pharmaceutical patent. In accordance to Industrial Property Law (IPL), the scope of patent prevention shall primarily be determined by the claims of the applicant. As high-budget research and development activities occur in pharmaceutical industry and by taking into account that the patent right includes the rights on generics, the claims on patent must be clearly defined. Rights on product patent of a pharmaceutical provide to its owner exclusive authority for manufacture, sale, use, import and possession of pharmaceutical for professional purposes. On the other hand, process patent of a pharmaceutical includes authority for use of the patented process, prohibition of making of offer by third parties for the unauthorized use of the patented process, prohibition of sale, distribution and commercial use of the products manufactured directly by implementation of the patented process by third parties, import, possession, implementation of the patented process for commercial use and offering to be made by third parties for execution of contracts for unauthorized use. In terms of prohibition of indirect use, patent owner of a pharmaceutical patent may also prohibit unauthorized delivery of items and instruments related to essential part of the patent by third parties which enables implementation of patent. Notwithstanding the above-mentioned wide scope of rights and powers arisen from patent, activities listed under article 85/3 of IPL and exempted from patent prevention are consisted of acts undertaken privately for noncommercial purposes, acts undertaken for experimental purposes and preparation of medicine in accordance with medical prescription which have non-commercial nature and are undertaken for personal needs and purposes. Acts undertaken privately for non-commercial purposes can be defined as acts including the use of patented product for personal needs and use for the needs of neighborhood. The legal grounds of this exemption can be specified as; use of patent for personal needs does not violate patent rights or constitute any risk for such and scientific advancements can be achieved by such use. Educational activities and gifting can be considered in the scope of this exemption. Acts for experimental purposes may also cause scientific advancements and ease inspection of the patent invention by third parties. The exemption concerning to preparation of medicine by a pharmacist in accordance with medical prescription which is outside the scope of commercial production can be based on customary law. Experimental acts listed under article 85/3 of IPL including 
those undertaken for obtaining pharmaceutical authorization and other related tests and trials are also classified as Bolar exemption and have critical importance in the area of pharmaceutical patent. As a result of this exemption generic pharmaceutical companies can execute the required trials and experiments for authorization, thus immediately after the expiration of patent term, they can participate in the market which may bring about a competitive medium. In case if Bolar exemption is not accepted by applicable law, generic pharmaceutical companies can realize manufacture and authorization of their products after a long period of time following the end of the patent term, as a result, the competitive medium which is necessary for public interest cannot be achieved at the end of the patent term. As a consequence of the specified reasons, in US law, Bolar exemption which is named after the court decision having the same name is accepted and following this incident such exemption is adopted by the EU law. Under Turkish law Bolar exemption is also recognized by the courts. Bolar exemption provisioned under Turkish law consists tests and trials required for authorization but excludes commercial production, storing and manufacturing prior to the end of patent term. In addition the application of Bolar exemption to data exclusivity enables generic pharmaceutical companies to file abbreviated application for authorization by depending on the data of the original pharmaceuticals which will result in accomplishment of the difficult and long-term authorization process. Under Turkish law Bolar exemption includes both abbreviated and standard applications for authorization and also obtaining of authorization falls under its scope. 


\section{Giriş}

Her ne kadar patent hakk1 $1^{1}$, ilaç üzerinde ürün ${ }^{2}$ ve/veya usule ${ }^{3}$ ilişkin sahibine geniş yetki ve haklar ${ }^{4}$ tanısa da konuyu düzenleyen yürürlükteki SMK'nın m. 85/3 hükmü uyarınca birtakım fiiller patent hakkı kapsamı dışında tutulmuştur. Nitekim mülga Pat. KhK. m. 75 hükmü ile de söz konusu istisnalara aynı içerikte olmak üzere yer verilmiştir. SMK m. 85/3 hükmü uyarınca; sınai veya ticari bir amaç taşımayan ve özel maksatla sınırlı kalan fiillerin, patent konusu buluşu içeren deneme amaçlı fiillerin, ilaçların ruhsatlandırılması ve bunun için gerekli test ve deneyler de dâhil olmak üzere patent konusu buluşu içeren deneme amaçlı fiillerin patent koruması kapsamında değerlendirilemeyeceği ifade edilmiştir. Yine aynı hükümde yer verilen, buluşun hava, karar ve deniz vasıtalarında kullanılmasi ${ }^{5}$ ve Milletlerarası Sivil Havacılık Antlaşmasında öngörülen fiiller ${ }^{6}$ ise, konumuzla ilgili olmaması nedeniyle inceleme dışında bırakılmışıır?

Patent sahibine tanınan korumanın kapsamı SMK m. 89 hükmüne göre istemlerle belirlenir ${ }^{8}$. SMK m. 89/2 hükmü uyarınca istemler hem patent sahibi hem de üçüncü

Genel anlamda patent hakkı buluş yapan kişiye buluşunu kullanma ve üçüncü kişiler tarafından kullanılmasını önleme hakkı verir. İlaç patentleri ise, konu bakımından ürün ve usul patenti olarak ikiye ayrılmaktadır. Konuya ilişkin detaylı açılamalar için bkz. Ayşegül Sezgin Huysal, İlaç Patenti, İstanbul, 2010, s. 157 vd.; Vildan Kayacan, İlaçta Patent Korumasının Etkileri ve Korunma Tedbirleri, Ankara, 2001, s. 1 vd., Fülürya Yusufoğlu, Patent Verilebilirlik Şartları, İstanbul, 2014, s. 379 vd. İlaç patentleri temel olarak ürün ve usul patenti olarak ikiye ayrılmakla birlikte ayrıntıda; form patenti, türev patenti, etkin madde karışım patenti, formülasyon patenti ve endikasyon patenti olmak üzere değişik türlere ayrılmaktadır. Ayrıntılı bilgi için bkz. Özgür Uğurluoğlu, “İlaç Sektöründe Fikri Mülkiyet Koruması”, Hacettepe Sağlık İdaresi Dergisi, C.17, S. I, 2014, s. 28-39; Koray Bulut, İlaçlar ve Sinai Haklar, http://farmapatent.com.tr/docs/Ilaclar_Ve_ Sinai_Haklar_Koray_Bulut.pdf, (Son Erişim Tarihi: 14.08.2018); Enver İzgü, İlaç ve Patent, Ankara, 1992, s. 1 vd.

2 Ürün patentini, buluşun ürün halinde somutlașması șeklinde ifade eden yaklaşım için bkz. Ünal Tekinalp, Fikri Mülkiyet Hukuku, İstanbul, 2012, s. 596, N. 36-5. Karş. Tahir Saraç, Patentten Doğan Hakka Tecavüz ve Hakkın Korunması, Ankara, 2003, s. 57. Ayrıca bkz. Arslan Kaya, "Türk Hukukunda Patentten Doğan Haklar", IÜHFM, C. LV, S. 4, 1997, s. 185; Uğur G. Yalçıner, “İlaç ve Patent, Türkiye'de ve Dünyada Son Gelişmeler, Ankara Barosu Fikri Mülkiyet ve Rekabet Hukuku Dergisi", C. 2, S. 3, 2002, s. 23.

3 Usul patentini, ürün ya da yan ürün oluşturan veya ürün niteliği taşımayan sonuçlar meydana getiren teknik ve sıralı olgular düzeni ve bu düzende kullanılan maddeleri belirleyip içeren çözüm şeklinde tanımlayan yaklaşım için bkz. Tekinalp, s. 596, N. 36-5. Ayrıca bkz. Yalçıner, İlaç ve Patent, s. 24; Nuşin Ayiter, İhtira Hukuku, Ankara, 1968, s. 44; Ernst Hirsch, Fikri ve Sinai Haklar, Ankara, 1948, s. 87.

4 Söz konusu yetki ve haklar aşağıda takip eden başlık altında ele alınacaktır.

5 SMK m. 85/3 hükmü uyarınca patent konusu buluşun Paris Sözleşmesi’ne taraf devletlerin gemi, uzay aracı, uçak veya kara nakil araçlarının yapımında veya çalıştııılmasında veya bu araçların ihtiyaçlarının karşılanmasında, söz konusu araçların geçici veya tesadüfi olarak Türkiye Cumhuriyeti sınırları içinde bulunması şartıyla kullanılması, patent hakkının istisnasını teşkil etmektedir.

6 5/6/1945 tarihli ve 4749 sayılı Kanunla onaylanan Milletlerarası Sivil Havacılık Anlaşmasının 27 nci maddesinde öngörülen ve bu madde hükümlerinin uygulandığı bir devletin hava aracı ile ilgili filler de patent hakkından istisna edilmiştir. Söz konusu madde anlaşmaya taraf devletlerden birine ait hava aracının ya da makine veya aksamının patente ilişkin haciz taleplerinden muafiyetini düzenlemektedir. Anılan düzenleme hakkında detaylı bilgi için bkz. http://mevzuat.shgm.gov. tr/umevzuat/kanun/4749_Sayili_Kanun_sikago.pdf, (Son Erişim Tarihi: 01.08.2018). Alman hukukunda PatG m. 11 'in 4. fikrası da benzer hüküm ihtiva etmektedir. Bu konuda bkz. Peter Mes, Patentgesetz Gebrauchsmustergesetz, 4. Auflage, 2015, PatG \&11, Rn. 1-17.

7 Yukarıda işaret edilen istisnaların yanısıra ilaç üzerindeki patentten doğan hakları geniş anlamı ile sınırlandıran, bir anlamda bunların istisnasını teşkil eden; patentin süresi, mülkilik ilkesi, paralel ithalat ve zorunlu lisans gibi yine hukuki dayanağını kanundan alan hukuki olgu ve düzenlemeler bulunmaktadır. Ancak anılan konular bu çalışmanın kapsamının dışındadır.

8 Shashank Upadhye, Generic Pharmaceutical Patent and FDA Law, U.S.A., 2008. s. 6; İlhami Güneș, Sınai Mülkiyet Kanunu Işı̆̆ında Uygulamalı Patent ve Faydalı Model Hukuku, Ankara, 2017, s. 54; Saraç, s. 47; Cahit Suluk (Rauf Karasu/Temel Nal), Fikri Mülkiyet Hukuku, Ankara, 2018, s. 264. Konu hakkındaki detaylı değerlendirmeler için ayrıca bkz. Kaya, Patentten Doğan Haklar, s. 179 vd. İstemlerin düzenlenişi hakkında ayrıntılı bilgi için bkz. Barış Atalay, Patent Vekilliği Uygulamalı Temel İlkeleri, İstanbul, 2013, s. 61 vd. Ayrıca bkz. Erdal Noyan, Patent Hukuku, 3. Baskı, Ankara, 
kişilerin menfaatlerini koruyacak şekilde yorumlanmal, ayrıca amaca uygun yorum yapılmalıdır 9 . Korumanın kapsamını belirlemede istemler kadar başvuru sahibinin beyanları da dikkate alınır ${ }^{10}$. AB hukukunda patent ile sağlanan korumanın kapsamı EPC m. 69 hükmü ile belirlenmiş olup korumanın kapsamı ve yorum ilkeleri bakımından SMK hükmüne paraleldir ${ }^{11}$. Aynı şekilde Alman PatG m. 14/1 hükmü de benzer şekilde kaleme alınmıştır ${ }^{12}$. Benzer bir hükümler İsviçre PatG m. 51'de de mevcuttur ${ }^{13}$.

SMK m. 89/5 hükmü uyarınca istemlerin yorumlanmasında dikkate alınacak başka bir kriter ise eşdeğer unsurlardır. Buna göre istemlerin yanısıra eşdeğer unsurlar da patentten doğan hakkın kapsamında korunmaktadır ${ }^{14}$. Bu düzenlemenin amacının patentte yer alan unsurların eşdeğerlerinin kullanılarak patentten doğan korumanın istismar edilmesini önlemek olduğu söylenebilir ${ }^{15}$.

Özellikle konumuz olan ilaç alanını ilgilendiren ve patent istemlerinin geniş bir kapsamı içerecek şekilde yapıldığı halleri, yani çok sayıda bileşeni içerecek şekilde yapılmasını ifade eden markush istemlerine ise, her ne kadar ülkemiz uygulamasında henüz pek rastlanılmasa da, anılan istemler ABD, Avrupa ülkeleri ve Avrupa Patent ofisi nezdinde başvurulara konu olmuş ve olmaktadır ${ }^{16}$. Söz konusu istemlere ilişkin olarak İngiliz ve İtalyan mahkeme kararları neticesinde başlıca iki kriterin

2015, s. 261. Buluşa ilişkin örnekler gösterilmişse bu örneklerin istemleri sınırlayamayacağına ilişkin değerlendirme için bkz. Hamdi Yasaman, Fikri ve Sınai Mülkiyet Hukuku (Fikir ve Sanat Eserleri Endüstriyel Tasarımlar Patentler İle İlgili Makaleler Hukuki Mütalâalar Bilirkişi Raporları), İstanbul, 2006, s. 383, 384. Patent hakkına tecavüz incelemesinde, istemlerin yorumunda, buluşun unsurlarında farklılık olup olmadığının inceleneceğine ilişskin bkz. İ. Yılmaz Aslan/Doğan Şenyüz/Mevci Ergün, İşletme Hukuku, Bursa, 2005, s. 297, 298.

9 Tekinalp, s. 605, N. 37-21.; European Patent Decisions Report, BGH of 22.02.2000- Positionierungsverfahren (XZR 111/98) Munich 2004, s. 149. SMK m. 89/2'nin gerekçesinde istemlerin yorumunda ne katı ne de genişletici bir yaklaşımın benimsenmemesi gerektiği ifade edilmiştir. Gerekçe için bkz. Ünal Tekinalp/Ersin Çamoğlu, Sınai Mülkiyet Kanunu, İstanbul, 2017, s. 147.

10 Bengt Domeij, Pharmaceutical Patents in Europe, Stockholm, 2000, s. 218; EPO, Guidelines for Examination in the European Patent Office, Munich, 2009, s. C IV, 11.7.2. Bu beyanlar, istemlerde yapılacak değişiklikler ve patentin geçerliliği süresinde yapılacak beyanları içerir. Ayrıca bkz. Saraç, s. 52-53.

11 EPC m. 69/1: “... patent istemlerinin içeriğine göre belirlenir. Bununla birlikte tarifname ve resimler, patent istemlerini yorumlamak için kullanılır."

12 Söz konusu hükme ilişkin detaylı değerlendirme için bkz. Uwe Scharen, Benkard Patentgesetz: PatG Gebrauchsmustergesetz, Patentkostengesetz, 11. Auflage, München, 2015. PatG \&14, Rn 1-4. Yazar hükmün, EPC m. 69/1 hükmüyle özdeş olduğu üzerinde durmaktadır. Ayrica bkz. Markus Ackermann, "Schütz ein Wirkstoffpatent vor "Prodrugs"?", GRUR, Heft 8, 2018, s. 772.

13 Hüküm hakkındaki değerlendirmeler için bkz. Peter Heinrich, PatG/EPÜ Schweizerisches Patentgesetz/Europäisches Patentübereinkommen - Kommentar in synoptischer Darstellung, 2010, Zürich, s. 282-383, N. 3, 4, 5.

${ }_{14} \mathrm{Bu}$ korumanın sebebinin patent hakkının sadece istemlerde yer alan unsurlar ile sınırlanmaması ve kelimelere bağlı yorumun reddedilmesine ilişkin yaklaşım olduğu yönünde bkz. Tekinalp, s. 605, N. 37-21.

15 Pierre Veron, Doctrine of Equivalents, Cambridge, 2001, s. 2. Eşdeğer kavramının doktrindeki tanımlanmasına ilişkin olarak bkz. Hirsch, s. 110; Ayiter, s. 90; Tekinalp, s. 605, N. 37-21. Eşdeğer doktrininin kabul edilmesindeki ana sebebin modern endüstri tekniği bakımından unsurların aynı olmasından ziyade bu unsurların işlevlerinin aynı olması olgusunun mevcudiyeti olduğu değerlendirmesi ve buna ilişskin açıklamalar için bkz. Sezgin Huysal, s. 153. Düzenlemenin amacının patentin kolay yollarla aşılmasını önlemek olduğu yönündeki yaklaşım için bkz. Murat Yıldırım, "İlaç Patentlerinde İstemlerin Yorumlanması”, Ankara Barosu Fikri Mülkiyet Hukuku Dergisi, 2006, C. 6, S. 2, s. 109.

16 Markush istemlerinin çok sayıdaki unsurun bileşimin bir ya da daha çok kısmında bulunduğu kimyasal yapılarda görüldüğüne ilişkin olarak bkz. M. Carlos Correa, "Pharmaceutical inventions: when is the granting of a patent justified?", Int. J. Intellectual Property Management, Vol. 1, No. 1/2, 2006, s. 10; Santanu Mukherjee, Markush Claims, Guide to Pharmaceutical Patents, Vol. II, Ed. M. Carlos Correa, Geneva, 2008, s. 63-64. 
benimsenmiş olduğu, bunların; istemde yer alan unsurlardan teknik bir uzmanın yaratıcı faaliyet gerçekleştirerek bulduğu unsurların koruma dışı kabul edilmesi ve patent hakkı ile sağlanan korumanın buluş sahibinin teknik katkısı kadar olması kriterleri olduğu söylenebilir ${ }^{17}$.

\section{Patent Hakkı Sahibine Tanınan Korumanın Kapsamı}

Patent hakk1 sahibine tekel niteliğinde yetkiler verse de, bu yetkilerin nelerden ibaret olduğunu ve sınırlarını belirlemek için, hele ki ilaç patenti söz konusuysa, yukarıda $^{18}$ açıklandığı üzere patentin konusuna göre yapılan ürün ve usul patenti ayrımı büyük önem taşımakta, buna göre korumanın kapsamı farklılaşmaktadır ${ }^{19}$. Ayrıca patente ilişkin koruma konusu değerlendirilirken patent unsurlarının dolaylı kullanımının da belirli şartlar dahilinde koruma kapsamında olduğunun vurgulanması gerekir (SMK m. 86).

\section{A. Ürün Patenti ile Sağlanan Koruma}

Ürün patenti bakımından, SMK m. 85/2-a hükmü, patent hakkından doğan korumanın kapsamını belirlemektedir. Anılan hüküm uyarınca hak sahibi, üçüncü kişiler tarafından patente konu ürünün üretilmesinin, satılmasının, kullanılmasının, ithal edilmesinin veya anılan amaçlar için kişisel ihtiyaçtan başka herhangi bir nedenle elde bulundurulmasının önlenmesini talep edebilir. Patent hakkı sahibinin anılan bu yetkileri aynı zamanda patentten doğan hakkın menfi etkisi olarak nitelendirilmektedir ${ }^{20}$. Hükümde yer verilen fiiller sınırlı sayıda olup doktrindeki eğilim, hak sahibinin, bu sayılanlar dışındaki fiilleri önlemeyi talep yetkisinin olmadığı yönündedir²1. Aynı zamanda söz konusu durumun, SMK m. 141 hükmünde sınırlı sayıda olmak üzere yer verilen patent hakkına tecavüz halleriyle ${ }^{22}$ paralellik arzettiği de söylenebilir ${ }^{23}$.

\footnotetext{
Söz konusu mahkeme kararlarına örnek olarak ise, İtalyan Yüksek Mahkemesi'nin Cimetidine ve İngiliz mahkemesinin Bigen v. Medeva kararları gösterilebilir. Bunlar hakkında detaylı bilgi için bkz. Santanu Mukherjee, Enabling Disclosure, Guide to Pharmaceutical Patents, Vol. II, Ed. M. Carlos Correa, Geneva, 2008, s. 47; Domeij, s. 320.

18 Bkz. dpn. 1, 2 ve 3.

19 Sezgin Huysal, s. 158; Suluk (Karasu/Nal), s. 274.

20 Kaya, Patentten Doğan Haklar, s. 184.

21 Kaya, Patentten Doğan Haklar, s. 186; Saraç, s. 56.

22 SMK m. 141/1 hükmü uyarınca patent hakkına tecavüz halleri özetle; buluș konusu ürünü üretme, tecavüz yoluyla üretilen ürünleri satmak, dağıtmak, ticaret alanına çıkarmak, ticari amaçla elde bulundurmak, izinsiz olarak patent konusu usulü kullanmak, söz konusu usulle elde edilen ürünleri satmak, dağıtmak veya başka bir surette ticaret alanına çıkarmak, ticari amaçla elde bulundurmak, patent hakkını gasp etmek, patente ilişkin lisans yoluyla verilen hakları izinsiz olarak genişletmek veya bu hakları üçüncü kișilere devretmek olarak listelenebilir. Bu meyanda ürün taklidi yoluyla patent hakkına tecavüze ilişkin Yargıtay'ın yaklaşımı değinmekte fayda vardır. Zira ürün taklidi, patent istemlerinin kullanılması yoluyla söz konusu olabilmektedir. Haklı olarak eleştirilen kararı uyarınca, Yargıtay, ürün taklidi yoluyla tecavüzün gerçekleşebilmesi için ana istemde belirtilen unsurların tamamının tecavüz ettiği iddiasında bulunulan ürünlerde bulunması gerektiğini içtihat etmiştir. Bkz. Yarg. 11. HD., 09.11.2009, 7278/11554, karar metni için ayrıca bkz. Güneş, s. 223-224. Oysa kanaatimizce, katı bir yorumla ana istemdeki tüm unsurların tecavüz iddiasında bulunulan üründe de bulunmasını șart koșmak isabetli bir yaklaşım olmayacaktır. Bizce ürünün karakteristiğini sağlayan önemli unsur veya unsurların üründe bulunması tecavüz değerlendirmesi için yeterli olmalıdır. Katıldığımız görüş için bkz. Güneş, s. 224.

23 Ayrıca bkz. Tekinalp, s. 638, N. 40-8. İlaç patentinin tarihi gelişim süreci içerisinde usul ve ürün patenti ayrımını kabul eden
} 
Ürün patenti hak sahibine kanunla belirlenmiş çerçeve içerisinde kalmak şartıyla patentli ürünün üretimi ${ }^{24}$, satış1 ${ }^{25}$, kullanım $1^{26}$, ithalatı ${ }^{27}$ ve kişisel amaç dışındaki nedenlerle elde bulundurulması konularında tekel hakkı sağlamaktadır ${ }^{28}$. Söz konusu haklar patent hakkının müspet etkisi olarak değerlendirilebilir ${ }^{29}$.

\section{B. Usul Patenti ile Sağlanan Koruma}

SMK m. 85/2.b, c ve ç bendi hükümleri uyarınca usul patenti, hak sahibine; patent konusu usulün kullanılmasını, kullanılmasının yasak olduğu bilinen veya bilinmesi gereken usul patentinin kullanılmasının üçüncü kişiler tarafından başkalarına teklif edilmesini, patent konusu usul ile doğrudan doğruya elde edilen ürünlerin satılması, kullanılması, ithal edilmesi veya bu amaçlar için kişisel ihtiyaçtan başka bir nedenle elde bulundurulmasını engelleme hakkı verir. Yukarıda ${ }^{30}$ değinildiği üzere bu yetkiler patent hakkının menfi etkisi kapsamındadır. Farklı kişilerin patentli veya patentsiz bir ürünün üretim usulü için farklı patentlere sahip olmaları mümkündür ${ }^{31}$. Patentli bir ürünün üretim usulüne ${ }^{32}$ ilişkin patent hakk1 elde edilmesi durumunda, üretim usulüne ilişkin patent sahibi kişinin ürün patentini ihlal etmeden hakkını kullanabilmesi, önceki patent sahibinin izni ve/veya sözleşmeye dayalı lisans ${ }^{33}$ vermesi dışında ancak kanunda yer verilen ve patent konuları arasında bağımlılığın

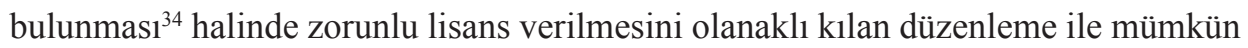
olacaktır (SMK m. 131) ${ }^{35}$. Bunun yanısıra ürünün patentli olmaması halinde aynı

ülkelerin çoğunun yakın denilebilecek zamana kadar ilaçta ürün patentini, endüstriyel gelişimi engelleyeceği gerekçesiyle reddetmiş oldukları gözlemlenmiştir. Bu konuda ayrıntılı değerlendirmeler için bkz. Michele Boldrin/David K. Levine, Against Intellectual Property, Cambridge, 2008, s. 62.

24 Üretim gerek ürünün tamamının üretimini gerek de ürünü oluşturan unsurların üretimini içerir. Bu konuda ayrıca bkz. Kaya, Patentten Doğan Haklar, s. 186.

25 Kiralama ve ödünç vermenin de patent hukuku anlamında satış olduğu yaklaşımı için bkz. Suluk(Karasu/Nal), s. 275.

26 Kullanım hazırlığına ilişkin çalışmaların da bu kapsamda değerlendirileceğine ilişkin görüş için bkz. Kaya, Patentten Doğan Haklar, s. 187.

27 SMK m. 152 hükmü uyarınca uluslararası tükenme ilkesi kabul edildiği için orijinal ürünün ithalatı ve bu bağlamda paralel ithalat ve geri ithalat serbesttir.

28 Benzer yöndeki değerlendirmeler için bkz. Suluk (Karasu/Nal), s. 274-275.

29 Kaya, Patentten Doğan Haklar, s. 184.

30 Bkz. yukarıda dpn. 20.

31 Uğur Yalçıner, “Türkiye'de İlaçta Patentin Bugünü ve Yarını”, Ankara Barosu Uluslararası Hukuk Kurultayı 2002, Ankara, 2002, s. 798-805; Kayacan, s. 72-76; Ayiter, s. 41.

32 Usul patentlerinin ikiye ayrıldığına, birinci türün üretim usulüne ilişkin olduğu diğer türün ise, usulün uygulandığı objede değişiklik meydana getirdiğine ilişkin açıklamalar için bkz. Kaya, Patentten Doğan Haklar, s. 188.

33 SMK m. 125 hükmü uyarınca patentin lisans sözleșmesine konu olması imkan dahilinde olup lisans sözleșmesi, inhisarî ve inhisarî olmayan (adi lisans) sözleşmesi şeklinde yapılabilir. İnhisarî lisans veren lisans verdiği kişiden başkasına lisans veremez. Bu konuda ayrıntılı bilgi ve değerlendirme için bkz. A. Necip Ortan, Patent Lisans Sözleşmesi, Ankara, 1979, s. 15-18; ayrıca bkz. Güneș, s. 194- 195. Adi lisans sözleşmesi ise, patent sahibini başkalarına da lisans verme konusunda sınırlamaz. Patente ilişkin lisans sözleşmelerine ilişkin değerlendirmeler için bkz. Tekinalp, s. 624, N. 38-9 vd.; Noyan, s. 589 .

34 Bağımlı patent SMK m. 131'de düzenlenmiştir. Buna göre; önceki patente tecavüz olmaksızın sonraki tarihli patent konusu buluşun kullanılması söz konusu olmazsa ikinci patent ilkine bağımlı patenttir. Ayrıca bkz. Ayşe N. Odman, Fikri Mülkiyet Hukuku ile Rekabet Hukukunun Teknolojik Yeniliklerin Teşvikindeki Rolü, Ankara, 2002, s. 337-338; Sezgin Huysal, s. 166-167. Örnekli açıklamalar için bkz. Suluk (Karasu/Nal), s. 236-237.

35 Zorunlu lisans SMK'da m.129 ila m. 138 arasında düzenlenmiştir. Makalenin inceleme planı nedeniyle detaylı yönleri olan bu konunun ayrıntısına girilmeyecektir. Konunun geneli hakkındaki detaylı değerlendirmeler için bkz. Arslan 
ürünün üretimi için birden fazla usul patenti alınması da söz konusu olabilir. $\mathrm{Bu}$ durumda tüm usul patenti sahipleri kendi usulleri ile ürünü üretip pazarlayabilirler ${ }^{36}$. Aralarında ihlal durumu ortaya çıktığında ise, SMK m. 141/2'de düzenlenen özel ispat hükmü devreye girecektir. Bu hükme göre, patentin yeni ürün veya maddelerin üretimine ilişkin bir usul olması halinde, üçüncü kişiler tarafından yapılan üretim, karine olarak, patentin ihlali kabul edilir ve üçüncü kişinin ihlal olmadığını ispat etme yükümlülüğü bulunacaktır ${ }^{37}$.

Usul patenti; fiilen patentli usulün kullanılması, usul patentinin kullanılmasının üçüncü kişiler tarafından başkalarına teklif edilmesi, usul ile doğrudan doğruya elde edilen ürünlerin satılması, dağıtılması veya başka suretle ticaret alanına çıkarılması, bu amaçlarla ithal edilmesi, elde bulundurulması, uygulamaya koymak suretiyle kullanılması veya bu ürünlerle ilgili sözleşme yapmak için öneride bulunulmasını önlemek konularında hak sahibine yetki vermektedir (SMK m. 141/1-c) ${ }^{38}$.

\section{Patent Unsurlarının Dolaylı Kullanımına İlişskin Koruma}

SMK m. 86 hükmü uyarınca, patent sahibi, patentli buluşun uygulanmasını mümkün kılan ve buluşun esasını teşkil eden bir kısmıyla ilgili unsurların veya araçların üçüncü kişiler tarafından yetkili olmayan kişilere verilmesini önleme yetkisini haizdir. Hükmün uygulanabilmesi için üçüncü kişilerin bu unsurların ya da araçların buluşu uygulamaya yeterli olduğunu ve bu amaçla kullanılacağını bilmeleri

Kaya, 551 Sayılı "Patent Haklarının Korunması Hakkında Kanun Hükmünde Kararname" ile Getirilen Zorunlu Lisans Sistemi, IÜHFM, C. LV, 1996, s. 335-267; Ayşe Boztosun Odman, İlaçta Zorunlu Lisans Uygulamaları, İlaç Hukuku, Erciyes Üniversitesi Hukuk Fakültesi I. Sağlık Hukuku Sempozyumu 08-09 Mayıs 2009, Ed. Murat Şen/Ahmet Başözen, İstanbul, 2009, s. 223-226. Ayrica bkz. M. Carlos Correa, Integrating Public Health Concerns into Patent Legislation in Developing Countries, Geneva, 2000, s. 101; Duncan Matthews, "WTO Decision on Implementation of Paragraph 6 DOHA Declaration on the TRIPS Agreement and the Public Health: A Solution to the Access to Essential Medicines Problem?", Journal of International Economic Law, C. 7, S. 1, s. 82; F. M. Scherer/Watal Jayashree, "Post-TRIPS Options for Access Patented Medicines in Developing Nations, Journal of International Economic Law", C. 5, S. 4, 2002, s. 926 ; M. Frederick Abbott/H. Jerome Reichman, "The DOHA Round's Public Health Legacy: Strategies For the Production and Diffusion of Patented Medicines under the Amended TRIPS Provisions", Journal of International Economic Law, C.10, S.4, s. 929. Alman PatG m. 24'de zorunlu lisans düzenlenmiş olup buna ilişkin değerlendirmeler için bkz. Rüdiger Rogge/Helga Kobber-Dehm, Benkard PatG \& 24, Rn. 1-8; BPatG: Zwangslizenz für Herstellung eines HIV-Medikaments - Isentress, GRUR, S. 4, 2017, s. 373-384. İsviçre PatG'de ise, m. 40 ila 40e arasında düzenlenmiştir. Ayrıca yine İsviçre PatG m. 29/III, 36 ve 37'de zorunlu patent hallerine ilişkin düzenlemeler mevcuttur. Zorunlu lisansın hukuki nitelik olarak şarta bağlı lisanslar başlığı altında incelenebileceği hakkındaki açıklamalar için bkz. Urs Zenhäusern, Vertragsverhältnisse Teil 1: Innominatkontrakte, Kauf, Tausch, Schenkung, Miete, Leihe, Handkommentar zum Schweizer Privatrecht Art. 184 - 318 OR, Hrsg. Markus Müller-Chen, Claire Huguenin, Zürich, 2016, s. 97, N.10. İlaç patenti alanını ilgilendiren özel bir düzenleme niteliğinde olan ve mülga Pat. KhK. m. 101/3'de patent konusunun kimyasal ve eczacilıkla ilgili bir maddenin elde edilmesine ilişkin bir usule ait olması ve önceki tarihli patente ilişkin önemli bir teknik gelişmeyi gerçekleştirmesi haline ilişkin olarak her iki patent sahibinin birbirine zorunlu lisans vermesini öngören hüküm, SMK m. 131/2'de yalnızca kimyasal ve eczacılıkla ilgili olarak değil tüm alanlara ilişkin olarak çok daha geniş şekilde tanınmıştır.

36 Yalçıner, Kurultay, s. 798.

37 Türk hukukunda, kanuni düzenlemede, TRIPS'in usul patentlerinin ispat yükümlülüğüne ilişkin 34. maddesinin birinci fikrasında yer alan ve ispat yükünü davalı tarafa yükleyen iki koşuldan sadece a bendinde yer alan patentli usulle elde edilen ürünün yeni olması koşuluna yer verildiği, b bendinde yer alan benzer ürünün büyük olasılıkla usul ile elde edilmiş olması ve patent sahibinin makul çabaları sonucunda fillen kullanılan usulü tespit edememiş olması koşuluna ise, aynı maddenin ikinci fikrasında belirtilen ve üye ülkelere, $\mathrm{b}$ bendini hukuklarında kabul etme konusunda serbesti tanıyan hükmünden istifade edilerek yer verilmediği yönündeki açıklamalar için bkz. Sezgin Huysal, s. 168, dpn. 541.

38 Konuya ilişkin detaylı açıklamalar için bkz. Kaya, Patentten Doğan Haklar, s. 188 vd.; Suluk (Karasu/Nal), s. $275-276$. 
veya bu durumun yeterine açık olması gerekir ${ }^{39}$. Anılan unsur veya araçların piyasada her zaman bulunabilen ürünler olmaları halinde hükmün uygulanabilmesi için üçüncü kişilerin söz konusu fiilleri yapmaya teşvik etmesi gerekir. Ayrıca SMK m. 85/3'de belirtilen fiilleri işleyen kişiler hükmün uygulanmasından istisna edilmiştir ${ }^{40}$.

\section{Sınai Mülkiyet Kanunu Madde 85/3 Hükmüyle İlaç Patenti Korumasından İstisna Edilen Fiiller}

\section{A. Sınai veya Ticari Amaç Taşımayan Özel Maksatla Sınırlı Kalan Fiiller}

SMK m. 85/3-a hükmü uyarınca sınai veya ticari bir amaç taşımayan ve özel maksatla sınırlı kalan, başka bir ifadeyle iktisadi amaçlı olmayan ${ }^{41}$ fiiller ilaç patenti koruması kapsamı dışındadır. İsviçre PatG'in aynı hükme karşılık gelen 9. maddesinin birinci fikra hükmünde de nicht gewerblichen Zwecken (ticari olmayan amaçlar) ifadesi kullanılmıştır ${ }^{42}$. Aynı ifade biçimi Alman PatG m. 11/1 hükmünde de yer almaktadı ${ }^{43}$. Özel maksatla kullanım, kişinin patentli ürünü kendisi veya yakın çevresinin ihtiyaçları için kullanması şeklinde ifade edilebilir ${ }^{44}$. Bu istisnanın tanınmasının nedeni olarak; özel kullanımlar neticesinde bilimsel merak ve bilgi artışının sağlanması, bu tür kullanımın patent tekeline karşı tehdit özelliği ya da potansiyelini barındırmaması gibi gerekçeler ileri sürülmektedir ${ }^{45}$. Bu tür kullanıma örnek olarak, bir kimya öğretmeninin usul patenti ile korunan öksürük ilacının bileşenlerini piyasadan temin etmek ve söz konusu usulü patent sahibinin izni olmaksızın aynen uygulamak suretiyle kendisi için kullanması gösterilebilir ${ }^{46}$. Özel maksatla kullanım ifadesinin işaret ettiği kişisel kullanım kavramının dar olarak yorumlanması gerektiği, özellikle kişinin sübjektif durumunun değerlendirmede dikkate alınması gerekeceği bir görüş tarafından ifade edilmiştir ${ }^{47}$. Kanaatimizce de bu yaklaşım yerindedir. Esasen kişisel kullanım söz konusu olduğunda bunun sınırlarının belirlenmesi konusunda elde her olay açısından geçerli olacak somut kriterler olmayacağına göre, her kullanımı kendi özel koşulları içerisinde değerlendirmek isabetli olacaktır.

Öte yandan aynı görüş ${ }^{48}$ tarafindan ileri sürülen "çok sayıda" kişiye hediye

\footnotetext{
39 Hükmün bu kısmının sübjektif şart niteliğinde olduğuna ve durumun yeterince açık olması lafzııın patent sahibinin ispat külfetini oldukça hafiflettiğine ilişkin değerlendirme için bkz. Kaya, Patentten Doğan Haklar, s. 190.

${ }^{40}$ Anılan hükümde istisna edilen fiiller, bu makalenin esas inceleme konusu kapsamında olup hemen aşağıda III no'lu ana başlık altında detaylı olarak ele alınacaktır.

${ }^{41}$ Bu niteleme için bkz. Kaya, Patentten Doğan Haklar, s. 192.

42 Hüküm hakkındaki değerlendirme için bkz. Heinrich, s. 196-197.

43 Scharen, Benkard PatG, PatG § 11, Rn. 3. Ticari kullanım ve bu kavram kapsamında görülemeyecek fiiller bakımından bkz. Volkmar Tetzner, "Patentverletzung durch Forschung", GRUR, Heft 11, 1966, s. 604-607.

44 Suluk (Karasu/Nal), s. 277.

45 Söz konusu gerekçeler için bkz. Güneş, s. 232.

46 Söz konusu örnek için bkz. Tekinalp, s. 607, N. 37-26,

47 Suluk (Karasu/Nal), s. 277.

48 Suluk (Karasu/Nal), s. 277.
} 
verilmesi halinde bunun hak ihlali teşkil edeceğine ilişkin tespite ise, kanaatimizce ihtiyatla yaklaşılması gerekir ${ }^{49}$. Zira bir yandan dar yorum kuralının benimsenmesi ve kişinin sübjektif durumunun dikkate alınması gereği ifade edilirken diğer yandan çok sayıda kişi gibi görece bir kavrama işaret edilmesi, bu meyanda hangi kullanımın hangi noktadan sonra kişisel kullanım sayılamayacağının tespitindeki zorluk nedeniyle genelleyici bir yaklaşımdan kaçınılması daha isabetli olacaktır.

Eğitim amaçlı fiiller, tasarımlar açısından belirli şartlar altında istisna kapsamında kabul edildiği halde, benzer bir hüküm patent konusunda bulunmamaktadır (SMK m. 59/3-c). Ancak böyle bir hüküm bulunmasa dahi patent koruması açısından da ele aldığımız iktisadi amaç taşımayan özel amaçlı kullanım kapsamına eğitim amaçlı kullanımların da dahil edilebileceği, burada hareketle eğitim istisnasının patentler açısından da geçerli olduğu görüşü doktrinde ileri sürülmüştür ${ }^{50}$. Ancak kanaatimizce bu durumda benimsenmesi gereken daha isabetli yaklaşım eğitim istisnasının tasarımda olduğu gibi patentte de geçerli olduğu olgusu yerine eğitim amaçlı fiillerin belirli şartlar altında bu başılık altında ele aldığımız özel amaçlı fiiller ya da aşağıdaki başlık altında inceleyeceğimiz deneme amaçlı fiiller kapsamında değerlendirilebileceğidir ${ }^{51}$. Aksi takdirde kanunda yer almadığ 1 halde yorum yoluyla genel geçer bir istisnanın varlığını kabul etmek her durumda isabetli olmayacaktır ${ }^{52}$.

Netice itibarıyla bu başlık altında yer verilen öksürük ilacı örneğinde olduğu üzere, daha ziyade kişisel ihtiyaçların karşılanması maksatlı olan ve bu amacın sınırlarını zorlamayacak nitelikteki özel amaçlı fiillerin, patent korumasından istisna edilmesi ilaç patenti açısından da haklı ve makul bir düzenlemedir.

\section{B. Deneme Amaçlı Fiiller}

Patent konusu buluşu içeren deneme amaçlı fiiller de SMK m. 85/3-b hükmü uyarınca patent koruması kapsamı dışında bırakılmıştır. Bu düzenlemenin amacının bilimsel gelişmeyi engellememek ve buluşun gerçeklik ve doğruluğunu kontrol etmek isteyen üçüncü kişiler tarafindan kullanılabilmesi sağlamak olduğu ifade edilmiştir ${ }^{53}$. Bu tür fiillerin daha ziyade eğitim amaçlı olabileceği düşünülse de sadece

\footnotetext{
49 Buna karşın ekonomik kazanç gayesi gütmeyen tüm kullanımların özel maksatla sınırlı kalan kullanım kapsamında değerlendirilmesi gerektiği ve bu nedenle patent hakkına tecavüz teşkil etmeyeceğine ilişkin görüş için bkz. Kaya, Patentten Doğan Haklar, s. 192; Saraç, s. 91.

50 Suluk (Karasu/Nal), s. 278. Yazar tarafından bu istisnadan yararlanılabilmesi için buluşun eğitimin süjesi olması gerektiği ifade edilmektedir.

51 Doktrinde eğitim amaçlı fiiller, kimi yazarlarca özel amaçlı fiiller istisnası, kimi yazarlarca da deneme amaçlı filller istinası kapsamında ele alınmaktadır. Bkz. Kaya, Patentten Doğan Haklar, s. 192; Suluk (Karasu/Nal), s. 277. Kanaatimizce söz konusu fiiller, nitelikleri gereği her iki istisna kapsamında da değerlendirilebilecek özellikte olup bu konuda kesin bir ayrımı savunmak isabetli olmayacaktır.

52 Eğitim amaçlı da olsa fazla sayıda kişiye patent konusu buluşun verilmesi halinde patent korumasının sınırları zorlanmış olacaktır.

53 Saraç, s. 94
} 
bu amaçla sınırlı olmadığı da ifade edilmelidir ${ }^{54}$. Bu konuda özellikle vurgulanmas1 gereken husus istisna kapsamındaki denemenin sadece patent konusu buluş ile ilgili olması gerektiğidir. Denemenin başka bir konu için yapılması ve buluşun bu nedenle kullanılıyor olması patent hakkı ihlalidir ${ }^{55}$. Başka bir görüş tarafından ise, bu düzenlemenin altında yatan başlıca gerekçe olarak patent tekelinin bilimsel gelişme ve meraka engel olmaması yaklaşımı gösterilmiştir ${ }^{56}$.

Bir görüş tarafından deneme amaçlı fiillerle aşağıda SMK m. 85/3-c kapsamında inceleyeceğimiz ilaçların ruhsatlandırılması için yapılan denemeler istisnasının birbirinden farkının, bu başlık altında incelediğimiz deneme amaçlı fillerin ekonomik bir çıkar elde etmek için yapılmıyor olması olduğu ileri sürülmektedir ${ }^{57}$. Bu konuda hükmün gerekçesi incelendiğinde, hükmün konulma amacının teknolojik gelişime katkıda bulunma olarak ifade edildiği görülmektedir ${ }^{58}$. Bu durumda gerekçenin de anılan yaklaşımı desteklediği ifade olunabilir. Buna karşın başka bir görüş tarafından ise, deneme amaçlı kullanımın ticari nitelik taşıyabileceği, ar-ge faaliyetine konu olarak ticari amaçla yapılabileceği yaklaşımı savunulmaktadır ${ }^{59}$. Kanaatimizce her ne kadar hükmün lafzında deneme amaçlı fillerin ticari niteliği haiz olup olmaması gerektiği konusunda bir açıklık yok ise de, buradan hareketle ticari amaçlı fillerin de bu kapsama gireceği yaklaşımı kolayca benimsenemez. Üstelik hükmün gerekçesi de anılan yaklaşımı desteklememektedir. Ayrıca bir an için hükmün lafzının müsait olmasından hareketle ticari amaçlı deneme fillerinin istisna kapsamında olduğunu kabul ettiğimiz takdirde, bu durumda, işaret ettiğimiz aynı fikranın takip eden c bendinde niçin ilaçların ruhsatlandırılması faaliyetine ilişkin özel bir düzenleme yapılma ihtiyacının doğduğu sorusu tatmin edici şekilde cevaplanamayacaktır. Kaldı ki, aşağıda ele alacağımız Bolar istisnasının kabul edildiği kaynak hukuk olan Amerikan hukukunda, istisnaya adını veren davada üst mahkemenin yaklaşımı patent hukukunda yer alan deneme amaçlı fiiller istisnasının ticari amaçlı fiilleri kapsamadığı yönünde olmuştur ${ }^{60}$. Dolayısıyla daha isabetli olan yaklaşım meseleyi bu açıdan değerlendirmektir.

\section{Reçete Uyarınca İlaç Hazırlanması}

SMK m. 85/3-ç hükmü uyarınca sadece reçetenin oluşturulması için seri üretim olmaksızın eczanelerde ilaç hazırlanması ve bunun kullanılması fiilleri de patent koruması dışında bırakılmıştır. TRIPS anlaşmasının 30. maddesi uyarınca da

\footnotetext{
Kaya, Patentten Doğan Haklar, s. 192.

Kaya, Patentten Doğan Haklar, s. 192.

'6 Söz konusu görüş için bkz. Güneș, s. 232

37 Sezgin Huysal, s. 181.

58 SMK m. 85/3-b bendi gerekçesi için bkz. Tekinalp/Çamoğlu, s. 141.

59 Suluk (Karasu/Nal), s. 278.

${ }_{60}$ Bkz. aşağıda dpn. 72 ve buna iliş̧in metin.
} 
eczanelerde sadece hastalar için hazırlanan ilaçlar patent hakkı dışında tutulmuştur ${ }^{61}$. Bir görüş tarafından eczanelere verilen bu yetkinin aynı zamanda örf ve adet hukukundan kaynaklandığ 1 ifade edilmiştir ${ }^{62}$. Anılan hüküm uyarınca kullanımın istisna kapsamında kalması için hükümde ifade edilen şartların bir arada bulunması gerekmektedir. Buna göre en başta kullanımın ilaca ilişkin olması zorunludur. İlaç kavramının kapsamına nelerin dahil olduğunun belirlenmesi de bu açıdan önem taşımaktadır. Kanaatimizce bu alandaki temel mevzuat olan İspençiyari ve Tıbbi Müstahzarlar Kanunu ${ }^{63}$ m. 1 ve devamındaki hükümlerden faydalanılması uygun olacaktır ${ }^{64}$. Bu itibarla eczanelerde satılan gida, tıbbi cihaz, kozmetik gibi ürünler ele aldığımız hüküm kapsamında değerlendirilemeyecektir.

Hüküm kapsamında kullanım olarak değerlendirilmesi için diğer şart ilacın eczanede yapılmış olmasıdır. Hükmün lafzı karşısında eczane dışında yapılacak ilaç hazırlama faaliyetinin istisna teşkil etmeyeceği söylenebilir. Ancak doktrinde hastane, sağlık ocağ hazırlanacak ilaçların hükmün kapsamında değerlendirileceği ifade edilmektedir ${ }^{65}$.

İlacın bir reçete uyarınca hazırlanmış olması da yine hüküm gereği gerçekleşmesi gereken bir şarttır. Reçete söz konusu olduğu için yapılacak ilacın bir doktor tarafından tavsiye edilmiş olması gereği de bulunmaktadır ${ }^{66}$.

Son olarak incelenen hüküm kapsamında yapılacak üretimin seri üretim olmaması mutlak surette gereklidir. Bu kapsamda söz konusu olacak üretim küçük bir işletme boyutuna ulaşacak düzeyde olmamalıdır ${ }^{67}$.

\section{D. İlaçların Ruhsatlandırılması ve Bunun İçin Gerekli Test ve Deneyleri de Kapsayan Deneme Amaçlı Fiiller- Bolar İstisnası}

\section{Genel Kapsam}

İlacın patentle korunması ile ruhsat alarak piyasaya sunulması birbirinden farklı iki sisteme dayanmaktadır. Bu sistemler fikri mülkiyete ve ruhsatlandırma

${ }^{61}$ Burcu G. Özcan Büyüktanır, “Türk Hukukunda İlaç Patentine Genel Bir Bakış”, Hacettepe Hukuk Fakültesi Dergisi, C. 2, S. 2, 2012, s. 86.

62 Tekinalp, s. 608, N. 37-28.

$63 \quad 26.05 .1928$ tarih ve 898 sayılı Resmi Gazete'de yayınlanmıştır.

${ }_{64}$ Kanun m. 1/1 hükmünde "Kodekste muharrer şekil ve formül haricinde ve fenni kaidelere muvafik muayyen ve sabit bir şekilde yapılacak amilinin ismiyle veya hususi bir nam altında ticarete çıkarılan tababette müstamel her nevi basit ve mürekkep devai tertiplere ispençiyari ve tıbbi müstahzarlar ismi verilir." şeklinde bir tanıma yer verilmiş, madde 2 'de de tıbbi müstahzar sayılmayacak ürünlere yer verilmiştir. İlaç tanımı açısından benzer yaklaşım için bkz. Sezgin Huysal, s. 180. İlacın bir hastalığın tedavi edilmesi veya önlenmesi amacıyla kullanılan maddeler olduğu şeklindeki tanımlama için bkz. Fülürya Yusufoğlu, "Jenerik İlaç ve Jenerik İlaç Ruhsat Başvurusunun Patente Tecavüz Çerçevesinde Değerlendirilmesi”, GSHFD, C.2, S. 2, 2014, s. 1156.

65 Suluk (Karasu/Nal), s. 279; Güneş, s. 232; Sezgin Huysal, s. 180.

66 Katıldığımız görüş için bkz. Suluk (Karasu/Nal), s. 280; Sezgin Huysal, s. 180.

${ }^{67}$ Kaya, Patentten Doğan Haklar, s. 192; Güneş, s. 232. 
sürecine ilişkin düzenlemelerden oluşur. Her ne kadar patent hakk1, sahibine, patent konusu buluş üzerinde inhisari kullanma ve yararlanma yetkileri sunsa da, ilaç söz konusu olduğunda ilacın piyasaya sürebilmesi için yetkili makam tarafından ruhsatlandırılması gerekecektir. Yapılan araştırmalar; AB'de bir ilaç için ortalama ruhsatlandırma süresinin, 9 ila 11 yıl arasında değiştiğini ${ }^{68}$ ortaya koymuştur. $\mathrm{Bu}$ durum ise, patentli ilaçlar bakımından ilacın efektif patent süresinin kısalmasına neden olmakta, eşdeğer-jenerik ${ }^{69}$ ilaçlar bakımından ise, ilacın piyasaya girmesini engelleyici rol oynamaktadır.

Patent süresinin sinırlı olarak belirlenmesi ile buluşu yapanla toplum menfaati arasında denge sağlanması amaçlanmıştır. Bu konuda toplum menfaatinin sağlanması ancak patent süresinin bitimini takiben buluş konusu ilacın eşdeğerlerinin de piyasaya arzı, bu sayede patent sahibinin patent hakkının fiilen de sona ermesiyle mümkün olabilecektir. Zira bunun neticesinde büyük olasılıkla birbirine rakip konuma gelen ilaçların fiyatları düşecek, ürün yelpazesinin de genişlemesiyle halkın ilaca erişimi kolaylaşacaktır ${ }^{70}$. Oysa ki, açıkladığımız üzere jenerik ilaçların da aynı şekilde tabi oldukları ruhsat prosedürü nedeniyle bu başlık altında incelediğimiz düzenleme mevcut olmasaydı, patent süresinin sona ermesiyle birlikte rekabetçi piyasa şartları hemen oluşamayacak, ancak bundan çok sonraki bir tarihte ruhsat alınmasından sonra eşdeğer ilaçlar piyasaya sunulabilecekti.

Ele aldığımız istisnanın mevzuatta düzenlenmesi gereği ilk defa ABD'de RocheBolar davasında verilen karar ile gündeme gelmiştir ${ }^{71}$. Bu davada orijinal ilaç üreten Roche şirketi, jenerik ilaç üreten Bolar şirketinin, flurezepam hcl isimli patentli etken maddesi üzerinde denemeler yaparak patent hakkına tecavüz ettiğini iddia etmiş, davalı Bolar şirketi ise, bu fiilin deneme amaçlı filler istisnası içerisinde kabul edilmesi gerektiği savunmasını getirmiştir. Federal Mahkeme'nin önüne gelen davada, yüksek mahkemenin yaklaşımı, söz konusu deneme amaçlı fiillerin patent hakkını ihlal ettiği yönünde olmuş, aynı kararda deneylerin ekonomik amaçla gerçekleştirilmesi halinde bunların deneme amaçlı filler istisnası kapsamında değerlendirilemeyeceği, bunun için yeni bir hukuki istisna yaratılması gerektiği görüşü benimsemiştir. Bu karar Amerikan hukukunda Bolar istisnası olarak isimlendirilen istisnanın tanınmasına ilişkin kanuni düzenlemelerin yapılmasına neden olmuştur ${ }^{72}$.

\footnotetext{
68 Domeij, s. 266.

69 Jenerik ilaç, orijinal ilacın eşdeğeri olan ilaçlardır. Ayrıntılı değerlendirme için bkz. Yusufoğlu, Jenerik İlaç, s. 1156. Jenerik ilaç etkinlik bakımından orijinal ilaçla eşdeğer olan ilaçtır ancak orijinal ilaçla aynı olmak zorunda değildir. Bkz. Tekin Memiş, Jenerik İlaçların Hukuki Konumu, Uluslararası Sağlık Hukuku Sempozyumu, Kadir Has Üniversitesi, İstanbul, 2008, s. 7-8

70 Correa, Integrating Public Health s. 69.

$71 \quad 733$ F.2d 858 (Fed. Cir. 1984).

72 K. Suresh Kumar/Aruna Tejswi/Shikha Tejswi, "Patent Laws and Research Exemption imperatives - do scientists have enough freedom to operate?", Current Science, Vol. 99, No. 11, 2010, s. 1525; Roche Products, Inc. Appellant, v. Bolar Pharmaceutical Co., Inc., Appellee, 733 F.2d 858 (Fed. Cir. 1984) https://law.justia.com (Son Erişim Tarihi: 12.09.2018); Christopher Garrison, Exceptions to Patent Rights in Developing Countries, UNCTAD-ICTSD Project on IPRS and Sustainable Development, Geneva, 2006, s. 14; John R. Thomas, Scientific Research and the Experimental Use Privelege
} 
Mahkemenin anılan kararı sonrasında Amerikan Federal İlaç, Gıda ve Kozmetik Kanunu'nda, Hatch-Waxman Act adıyla bilinen kanunla değişiklik yapılmış ve bu değişiklik neticesinde Bolar istisnası ilkesi kanunlaşmıştır ${ }^{73}$.

\section{Bolar İstisnası ve Veri İmtiyazı}

Veri imtiyazı, orijinal ilaç üreticisi tarafından üretilen verinin başka kişi veya tüzel kişi tarafından belirli bir süre kullanılamaması ya da referans gösterilememesi olarak tanımlanabilir ${ }^{74}$. Jenerik ilaç üreten firmalar ruhsat için başvuruda bulunurken kendi ürünlerinin niteliğine, kimyasal ve biyolojik olarak orijinal ürüne eşdeğer olduğuna ilişkin verileri sunmanın yanısıra sunmaları gereken klinik ve klinik öncesi deneme verilerine ilişkin olarak orijinal ürünün verilerine atıf yapmakla yetinebilirler. $\mathrm{Bu}$ uygulamaya kısaltılmış ruhsat başvurusu denilmektedir. $\mathrm{Bu}$ sayede jenerik ilaç firmaları uzun yıllar süren ar-ge çalışmaları, klinik test ve araştırmaları yapmaksızın orijinal ilacın ruhsat dosyasındaki verileri kullanarak ruhsat alabilmekte, böylece piyasaya çok daha hızlı ürün arzedebilmektedirler.

Veri imtiyazının, kısaltılmış ruhsat başvurusunun, jenerik ilaç üreticileri ve halka sağladığı avantajlar ile orijinal ilaç üreticilerine getirdiği dezavantajlar arasında denge kurabilme ihtiyacından doğduğu söylenilebilir ${ }^{75}$. Veri imtiyazı sahibine, sadece veriler üzerinde münhasıriyet sağlamakta olup, patent korumasından farklı olarak aynı ya da benzer verilerin yeniden geliştirilerek ticari olarak kullanılmasını önleme işlevi bulunmamaktadır ${ }^{76}$. Veri imtiyazı aynı zamanda ilaçlara özgü bir fikri mülkiyet korumasıdır ${ }^{77}$. Veri imtiyazı ve patent koruması sayesinde orijinal ilaç üreten firmaların araştırma ve geliştirme faaliyetleri teşvik edilmiş olmaktadır.

Veri imtiyazı, prensip olarak, Türkiye'de ilk ruhsat başvurusunu takiben altı y1l boyunca aynı verilere dayanarak başka bir firmanın ruhsat başvurusunda bulunmasını

in Patent Law, CRS Report for Congress, CRS Web Order Code RL32651, 28.02.2004, s. 14-15, https://fas.org/sgp/crs/ RL32651.pdf, (Son Erişim Tarihi: 12.09.2018).

73 Wendy H. Schacht, John R. Thomas, Patent Law and Its Application to the Pharmaceutical Industry: An Examination of the Drug Price Competition and Patent Term, Restoration Act of 1984, CRS Report for Congress, CRS Web Order Code RL30756, 2005, s. 24, https://fas.org, (Son Erişim Tarihi: 12.09.2018); Correa, Integrating Public Health, s. 69. Ayrıca bkz. Thomas, s. 14.

74 Karin Timmermans, "Monopolizing Clinical Trial Data: Implications and Trends", PLOS Medicine, https://journals.plos. org, (Son Erişim Tarihi:10.09.2018), Volume 4, Issue 2, 2007, s. 206; Tanım için ayrıca bkz. Uğur Çolak, Kısaltılmış Ruhsat Başvurusundan Kaynaklanan Hukuki Uyuşmazlıklar ve Veri İmtiyazı Uygulaması, Fikri Mülkiyet Yıllığı, 2009, s. 231. Çeşitli boyutları olan veri imtiyazı, sadece makale konusu bağlamında ele alınacak, diğer detay ve ayrıntılarına ve veri koruması konusuna girilmeyecektir.

75 Yasemin Aktaş, "Veri İmtiyazı Koruması ve Bolar İstisnasının Bu Koruma Üzerindeki Etkisi”, FSHD, C. 13, S. 49, 2009, s. 39.

76 Sirrı Düğer, Non-Patent Protection of Pharmaceuticals in Turkey, Aachen, 2012, s. 20-22. Patent koruması ve veri imtiyazı arasındaki farklar hakkındaki detaylı değerlendirme için ayrıca bkz. Uğurluoğlu, s. 34-35.

77 Cahit Suluk, "Türkiye'de İlaçların Patent ve Diğer Fikri Mülkiyet Hakları ile Korunması”, Terazi Hukuk Dergisi, C. 9, S. 100, 2014, s. 732; Aktaş, s. 39; International Federation of Pharmaceutical Manufacturers Associations, Encouragement of New Clinical Drug Development: The Role of Data Exclusivity, Geneva, 2000, s. 1; Tamer Baykara/Hülya Çaylı/Hüseyin Çelik/ Mehmet Tokat/Turgay Ünalan, Türkiye'de İlaçta Veri Koruması ve Uygulanmasının Mali Etkileri, Ankara, 2003, s. 12. 
engellemektedir ${ }^{78}$. Patent hakkının konusu yeni bir molekül ya da ilaç bileşiminin bulunması iken, veri imtiyazının konusu ürünler yeni bir kimyasal madde niteliği taşımalıdır ${ }^{79}$.

Türkiye'deki uygulamaya bakıldığında veri imtiyazı, Bolar istisnasına benzer şekilde jenerik ilaç firmalarının ruhsat başvurusu yapmalarına, hatta ruhsat almalarına engel olmayıp onların satış izni almalarını engellemektedir ${ }^{80}$.

\section{Mukayeseli Hukukta Bolar İstisnası}

\section{a. Amerikan Hukuku}

Yukarıda ${ }^{81}$ açıklandığı üzere Bolar istisnasının kabulü ilk olarak ABD hukukunda gerçekleşmiştir. Buna ilişkin karardan sonra ruhsat başvurusuna konu testlerin patent koruması dışında kalmasına Bolar istisnası denilmiştir ${ }^{82}$. Bu karardan sonra da, deneysel amaçlı fiillerin patent hakkına tecavüz etmediğine ilişkin olarak kabul edilen ilk kanun olan Hatch-Waxman Act adlı kanun ile patentli farmasotikler, tıbbi cihazlar ve FDA tarafından düzenleme yapılabilen bir kısım ürünler patent tecavüzü kapsamı dışında kalmıştır. Esasen Amerikan hukukunda deney amaçlı fiillerin patent koruması kapsamı dışında bırakılmasına ilişkin ilk kararın 1813 tarihli Whittemore v. Cutter kararı olduğu ifade edilebilir ${ }^{83}$.

Hatch-Waxman kanunundan önce ABD'de jenerik ilaç firmaları, üretecekleri jenerik ürünün güvenli ve etkili sayılması amacıyla FDA'dan onay alabilmek için pahalı ve uzun süren deneyler yapmak zorunda kalmaktaydılar. Ayrıca 1980'leri başından itibaren patentle korunan orijinal ilacın bulunmasına rağmen jenerik ilaç firmalarının klinik deneyleri yapıp yapamayacağı tartışma ve belirsizlik konusu olmuş, Federal Mahkeme'nin verdiği Bolar kararını takiben Hatch-Waxman kanunuyla patent ile ilaç ve gıda mevzuatında yapılan değişikliklerle ruhsat alımının hızlandırılması dahil olmak üzere jenerik ilaç firmalarının da kaygılarını gözeten düzenlemelere gidilmiştir ${ }^{84}$. Amerikan hukukundaki söz konusu sürecin mahkeme kararları açısından seyri de önem taşımaktadır.

Nitekim Eli Lily and Co v. Medtronic davasında verilen karar ile Temyiz Mahkemesi Hatch-Waxman kanunu kapsamına girecek ürünler konusuna açıklık

\footnotetext{
78 19.01.2005 tarih ve 25705 sayılı RG'de yayınlanan Beşeri Tıbbi Ürünler Ruhsatlandırma Yönetmeliği, m. 9/3.

79 IFPMA, s. 16; Hasibe Işıklı, İlaçlarda Test ve Deney Verilerinin Korunması: Avrupa Birliği’nde Yeni Sistem, İktisadi Sektörler ve Koordinasyon Genel Müdürlüğü Hukuki Tedbirler ve Kurumsal Düzenlemeler Dairesi, Ankara, 2005, s. 11.

80 Suluk, s. 733.

81 Bkz. dpn. $71 \mathrm{vd}$. ile ilgili olduğu metin.

82 Bolar istisnasına ilişkin olarak Amerikan hukukunda verilmiş başka kararlar için bkz. Yıldırım, s. 131 vd.; Memiş, Jenerik İlaç, s. 9-11; Tekin Memiş, İlaçların Patentlenmesi, İlaç Hukuku, Erciyes Üniversitesi Hukuk Fakültesi I. Sağlık Sempozyumu 08-09 Mayıs 2009, Ed. Murat Şen/Ahmet Başsözen, İstanbul, 2009, s. 212.

83 Thomas, s. 2.

84 Thomas, s. $14 \mathrm{vd}$.
} 
getirerek, ilaçlarla birlikte medikal aletler, yiyecek katkı maddeleri, renklendiriciler ve biyolojik ürünlerin de Amerikan Federal İlaç, Gıda ve Kozmetik Kanunu anlamında istisna kapsamında olduğunu belirtmiştiri ${ }^{85}$.

Integra Life Sciences v. Merck kararında ise, Federal Mahkeme'den sonra Temyiz Mahkemesine önüne gelen davada Temyiz Mahkemesi, Bolar istisnasının doğrudan FDA onayı için gerekli olmasa bile bu onayın verilmesi için gerekli tüm testleri kapsadığını, makul ölçüde ilgili tüm testlerin bu kapsama girdiğine hükmetmiştir ${ }^{86}$.

\section{b. Avrupa Birliği Hukuku}

Bolar istisnas1 AB hukukunda 2001/83/EC sayılı Direktif'de 2004/27/EC sayıl1 Direktif ile yapılan değişiklik neticesinde kabul edilmiştir. 2001/83/EC sayılı Direktif' in Bolar istisnasını düzenleyen 10/6 madde hükmü lafzında veri imtiyazı ile bağ kurularak veri imtiyazına ilişkin hükümlerin uygulanması ya da başkaca uygulamaya yönelik gereklilikler nedeniyle yapılan çalışma ve denemelerin ilaçlarda patent hakkını ihlal etmeyeceği hükme bağlanmıştır ${ }^{87}$. Bolar istisnasının $\mathrm{AB}$ tarafindan mevzuatla kabul edilmesinin tetikleyen olayın Bolar istisnasının TRIPS'e uygunluğunun DTÖ Anlaşmazlıkların Halli Organı tarafından teyit edilmesi olduğu ifade edilmiştir ${ }^{88}$.

AB'de Bolar istisnasının kabul edilmesinin arka planında ekonomik gerekçelerin de bulunduğu ileri sürülmüştür ${ }^{89}$. Nitekim Avrupa Eşdeğer İlaçlar Birliği tarafindan AB'de Bolar istisnasının kabul edilmemesi yüzünden $\mathrm{AB}$ içinde yapılacak araştırma faaliyetlerinin başka ülkelerde yapıldığı rapor edilmiştir. Bunun sonucu olarak da AB'nin önemli bir parasal kayba uğraması söz konusu idi ${ }^{90}$.

Bolar istisnasının düzenleniş şekli ve kapsamı AB üyesi ülkelerde farklılık arzetmektedir. Kimi üye ülkelerde patent mevzuatı içerisinde düzenlenmekte, bir kısım üye ülkede ise, hem patent hem de ilaç mevzuatı içerisinde düzenlenmektedir ${ }^{91}$. Ayrıca kimi üye ülkelerde etkin madde üretimi yapılabilirken, kimisinde sadece ruhsatlandırma amaçlı test ve deneyler yapılabilmektedir ${ }^{92}$.

Bolar istisnası bakımından Amerikan sistemi ile AB Direktif'i düzenlemeleri aynı

\footnotetext{
85 Thomas, s. 16.

86 Kumar/Tejswi/Tejswi, s. 1526-1527; Esmond W. Robert/Robert A. Schwartzman, "The Patent Infringement Exemption Land Grab", Intellectual Property \& Law Journal, Vol. 17, No. 6, 2005, s. 13-14; Marjan Noor/Camilla Smith, EU Strikes Balance With New Bolar Provision, Managing Intellectual Property, London, 2005, s. 5.

87 Pharmaceuticals Policy and Law, Vol. 11, No.4, 2009, s. 531.

88 Correa, Integrating Public Health, s. 70. Ayrıca bkz. Sezgin Huysal, s.184-185.

89 Ișıklı, s. 33.

90 Ișıklıl, s. 33 .

91 Mevzuatta düzenleniş şekline göre farkl1lık gösteren bu ülkelerin listesi için bkz. Avrupa Eşdeğer İlaç Birliği, 13. Yıllık Konferans Bilgi Notu, http://www.ieis.org.tr (Son Erişim Tarihi: 14.09.2018), s. 7.

92 Sezgin Huysal, s. 186.
} 
olmayıp farklılık arzetmektedir. Nitekim Direktif'de yer alan, “önemli uygulama ihtiyaçlarının gerçekleştirilmesi”, "çalışmalar ve denemeler” gibi ifadelerle Bolar istisnasının uygulanmasına kısıtlama getirildiği söylenebilir ${ }^{93}$. Zira bu durumda ithalat, ihracat gibi faaliyetlerin bu kapsama girip girmediği konusunda belirsizlik doğmaktadır. Öte yandan bu tür açık olmayan ifadelere yer verilmesinin bilinçli bir tercih ürünü olduğu, bu sayede Bolar istisnasının kapsamının ulusal mahkemelerce yorum yoluyla belirlenmesinin amaçlandığı ifade edilmiştir ${ }^{94}$. Zaten üye ülke uygulamaları da bu anlamda farklılaşmaktadır ${ }^{95}$.

\section{c. Alman ve İsviçre Hukukları}

Alman hukukunda 2004/27/EC sayıl1 Direktif öncesi dönemde deneysel kullanım istisnasına ilişkin hükümlerin kaynağı Avrupa Topluluğu Patent Konvansiyonu idi ${ }^{96}$. $\mathrm{Bu}$ dönemde Alman hukukunda iki mahkeme kararı belirleyici olmuştur. Bunlardan ilki olan Klinik Denemeler I kararında ${ }^{97}$ deneme amaçlı fiillerin ticari amaçla yapılmasının patent tecavüzü olarak değerlendirilemeyeceğine hükmedilmiştir.

Klinik Denemeler II kararında ${ }^{98}$ ise, yapılan denemeler neticesinde patent konusu buluş hakkında yeni bilgilerin bulunmasının amaçlanmasının patent ihlali kabul edilemeyeceğine içtihat edilmiştir.

Bolar istisnası 06.09.2005 tarihli revizyonla Alman PatG m.11/2-b hükmünde düzenlenmiştir. Anılan hüküm metin olarak incelendiğinde Avrupa Direktif'indeki metnin benzeridir.

İsviçre PatG m. 9'da 22.06.2007 tarihli kanunla yapılan değişiklik sonrası m. 9/1c hükmü olarak Bolar istisnasına yer verilmiştir ${ }^{99}$. Madde hükmü ruhsat alınması için gerekli fiillerin patent koruması dışında olduğu lafzını içermektedir ${ }^{100}$. Ancak söz konusu değişiklik öncesi dönemde de İsviçre mahkemelerinin yaklaşımının ruhsat amaçlı klinik denemelerin patent hakkını ihlal etmediği yönünde olduğu söylenebilir ${ }^{101}$.

\footnotetext{
3 Yildırım, s. 138.

94 Noor/Smith, s. 3.

95 Noor/Smith, s. 5.

${ }_{96}$ Kevin Iles, "A Comparative Analysis of the Impact of Experimental Use Exemptions in Patent Law on Incentives to Innovate", Northwestern Journal of Technology and Intellectual Property, Vol. 4, No. 1, 2005, s. 77.

97 Klinische Versuche 1, [1997] R.P.C 623; BGH: BGH 11.07.1995 X ZR 99/92 "Klinische Versuche”, GRUR, Heft 1.,1996, s. $58-60$.

98 BGH Patentrechtliches Versuchsprivileg - Klinische Versuche II, NJW, Heft 46, 1997, s. 3092-3096.

99 Söz konusu değișikliklerin AB ve Amerikan hukuku ile uyumlu olduğu yönündeki açıklamalar için bkz. Botschaft zur Änderung des Patentgesetzes und zum Bundesbeschluss über die Genehmigung des Patentrechtsvertrags und der Ausführungsordnung vom 23. November 2005, s. 73.

100 Cyrill P. Rigamonti, "Die Schweiz und das materielle Recht der Patentverletzung in Europa”, SIC!, S. 4, 2014, s. 243.

101 “Amlodipin” Obergericht Thurgau vom 7. April 2005 (Massnahmeentscheid), SIC!, S. 4, 2006, s. 417-419.
} 


\section{d. Türk Hukuku}

Türk hukukunda Bolar istisnası ilk defa 22 Haziran 2004 tarihinde mülga Pat. KhK'da yapılan değişiklikle kabul edilmiştir. Mülga Pat. KhK m. 75/f hükmü, yürürlükteki SMK m. 85/3-c hükmü ile neredeyse aynı olan bir içeriğe sahip olarak, ilaçların ruhsatlandırılması için gerekli test ve deneyler dahil olmak üzere tüm deneme amaçlı fiilleri patent hakkı dışında bırakmaktaydı. Söz konusu değişiklikle ilgili olarak Adalet Komisyonu gerekçesinde, Türkiye ve AB arasındaki 2/97 sayılı ortaklık konseyi kararı, TRIPS m. 39/3 hükmü ve 551 sayılı Pat KhK'nin 83. maddesinin üçüncü fikrasına ilişkin görüşlerin ileri sürüldüğü ifade edilmiştir ${ }^{102}$.

Yargıtay ise, vermiş olduğu kararlarda ihtisas mahkemelerinin Bolar istisnasını uygulayan kararlarını onamaktadır ${ }^{103}$.

Bolar istisnasına ilişkin SMK m. 85/3-c hükmü lafzı ve gerekçesi değerlendirildiğinde, Türkiye'de kabul edilen Bolar istisnas1, sadece ruhsat işlemlerinin yapılması için gerekli test ve deneyleri kapsamakta, patent süresi dolmadan seri üretim yapılması, depolama ve satışa sunulma filleri söz konusu istisnanın dışında kalmaktadır ${ }^{104}$. Aynı zamanda patent süresi dolmadan numune üretimi, etkin madde hazırlanması, üretilmesi filleri de Bolar istisnası kapsamında kabul edilmemektedir.

Bolar istisnası veri imtiyazı kapsamındaki deney ve testleri de kapsamaktadır ${ }^{105}$. $\mathrm{Bu}$ filllerin somut olarak tespiti için konuyu düzenleyen mevzuat olan Beşeri Tıbbi Ürünler Ruhsatlandırma Yönetmeliği’nin incelenmesi gerekir ${ }^{106}$. Yönetmelik m. 8 hükmü ilacın piyasaya sürülmesinden önce hangi deneylerin yapılması gerektiğini içermektedir ${ }^{107}$. Yönetmelik m. 9 hükmü ise, kısaltılmış başvuru usulü ve veri imtiyazını düzenlemekte, jenerik ilaç üreticilerinin, orijinal ilaç üreticilerinin ruhsat otoritelerine sunmuş oldukları verilere atıf yaparak ruhsat almalarını prensip olarak engellememektedir ${ }^{108}$. Meseleye Bolar istisnası açısından yaklaşıldığında, Yönetmelik m. 9'da düzenlenen kısaltılmış başvuru usulüne uygun ruhsat talebi halinde Bolar istisnasının kapsamına anılan usul gereğince yapılması gereken deneyler de girecektir.

Öte yandan, doktrinde ifade edildiği üzere SMK m. 85/3-c hükmü uyarınca Bolar istisnasının kapsamına ilacın ruhsatlandırılması ve bu meyanda kısaltılmış

\footnotetext{
102 26.04.2004 tarih, 1/740 E. ve 51 K. no'lu TBMM Adalet Komisyonu Raporu, s. 4, https://www.tbmm.gov.tr/tutanaklar/, (Son Erişim Tarihi: 08.01.2019).

103 Yarg. 11. HD., 04.10.2010, 3294/9581 (Güneş, s. 242); Yarg. 11. HD., 17.02.2011, 859/1835 (Güneş, s. 242).

104 Sezgin Huysal, s. 187.

105 Sezgin Huysal, s. 190.

106 Dilek İlter, İlaçların Ruhsatlandırılması ve Piyasaya Sürülmesi Usulü, İlaç Hukuku, Erciyes Üniversitesi Hukuk Fakültesi I. Sağlık Hukuku Sempozyumu 08-09 Mayıs 2009, Ed. Murat Şen/Ahmet Başsözen, İstanbul, 2009, s. 276.

107 Söz konusu deneylerin içereceği klinik çalışmalar hakkında bilgi için bkz. Selda Emre Aydıngöz, "Ruhsatlandırma Öncesi ve Sonrası Klinik İlaç Araştırması Tasarımları", İKU Dergisi, S.15, 2006, s. 7.

108 Uygulamada ruhsat alımının dahi gerçekleşebildiği sadece satış izni aşamasında söz konusu engelin ortaya çıktığı görülmektedir. Bkz. yukarıda dpn. 80 .
} 
ruhsat başvurusu da dahildir ${ }^{109}$. Böylece patent süresi dolmadan jenerik ilaca ruhsat verilmesi patent hakkını ihlal etmeyecektir ${ }^{110}$.

Uygulamada bu konudaki Türk yargı içtihatları da açıkladığımız şekilde gelişmiştir. Nitekim kısaltılmış ruhsat başvurusuna ilişkin olarak Yargıtay 11. Hukuk Dairesi, kısaltılmış ruhsat başvurusunda bulunmayı; dava konusu ilacın üretildiğine ya da herhangi bir şekilde ticaret alanına konulduğuna delalet etmeyeceği, bu aşamada henüz ruhsat veya satış izni verilmediğinden ilacın fiilen üretimi ya da piyasaya sürülmesinin mümkün olamayacağı, bu şartlarda patent hakkını ihlal eden bir fiilin söz konusu olmadığı gerekçesiyle hukuka uygun bulmuştur ${ }^{111}$.

İlacın ruhsat almış olması halinde dahi yargı içtihatları uyarınca ortada henüz patent hakkını ihlal eden bir durum yoktur. Zira ruhsatlandırılmış bir ürünün satışa sunulabilmesi için satış izni alınması gerekmekte, Beşeri Tıbbi Ürünler Ruhsatlandırma Yönetmeliği hükümleri uyarınca Sağlık Bakanlığı'ndan satış izni alınmayan hiçbir beşeri tıbbi ürünün satışa sunulması mümkün olmamaktadır ${ }^{12}$. Anılan Yönetmelik m. 20 ve m. 26/1 hükümleri gereğince ruhsatın alınması ürünün satışa çıkarılacağı anlamına gelmemektedir. Yargıtay'ın kararları da bu yaklaşımı yansıtmaktadı1 ${ }^{113}$. Kaldı ki yine Yargıtay kararları uyarınca ilaç ruhsat başvurusunda bulunulması patent hakkına tecavüz ya da haksız rekabet oluşturmamakta, ruhsat prosedürüne ilişkin idari işlem tamamlanmadan bir tecavüz tehlikesi de söz konusu olmamaktadir ${ }^{114}$.

\section{Sonuç}

Patent hakkından doğan korumanın kapsamı SMK uyarınca istemlerle belirlenir. İstemlerin yorumlanmasında ise, patent hakkı sahibine gereken korumanın sağlanması ama aynı zamanda üçüncü kişilerin haklarının korunması gözetilmelidir. Bu amaçla korumanın kapsamı tespit edilirken yapılacak yorum üçüncü kişiler açısından makul bir kesinlik arzetmelidir. Patent koruması kapsamı belirlenirken bir yandan da hak sahibinin beyanları dikkate alınmaktadır. Söz konusu kapsama eşdeğerler de dahildir. Ancak ilaç patenti özelinde ar-ge maliyetlerinin yüksek olması eşdeğer doktrini bakımından istemlerin mümkün olduğunca tartışmaya yer vermeyecek şekilde düzenlenmesini gerekli kılmaktadır.

\footnotetext{
109 Aktaş, s. 75 vd.; Yusufoğlu, Jenerik İlaç, s. 1174; Suluk, s. 733.

110 Suluk, s. 733; Sezgin Huysal, s. 190; Memiş, İlaçların Patentlenmesi, s. 213

11 Yarg. 11. HD., 17.02.2011, 859/1835 (Güneş, s. 242-245). Aynı karar için bkz. İlaç Patenti Tecavüzüne İlişkin Venlafaksin Kararı, http://fikrimülkiyetplatformu.org, (Son Erişim Tarihi: 16.09.2018).

112 Konuya ilişkin detaylı açıklamalar için bkz. Yusufoğlu, Jenerik İlaç, s. 1171 vd.

113 Yarg. 11. HD., 05.07.2012, 4500/12019 (Yusufoğlu, Jenerik İlaç, s. 1172 vd.); Yarg. 11. HD., 03.07.2012, 4498/11785 (Yusufoğlu, Jenerik İlaç, s. 1172 vd.); Yarg. 11. HD., 11.09.2012, 449/13033 (Yusufoğlu, Jenerik İlaç, s. 1172 vd.).

114 Yarg. 11. HD., 23.10.2008, 3574/11727 (Çolak, s. 279); Yarg. 11. HD., 03.02.2009, 6358/1166 (Çolak, s. 279 ); Yarg. 11. HD., 02.04.2009, 6521/4003 (Çolak, s. 279-280). Konuyla ilgili yargı kararları ve buna ilişkin değerlendirmeler için ayrıca bkz. Aktaş, s. 73 vd.
} 
SMK m. 85/3'de listelenen fiillerin gerçekleştirilmesinin patent hakkını ihlal etmeyeceği anılan kanun hükmü gereğidir. Hükümde yer verilen özel maksatla sınırlı kalan fiiller, reçete üzerine ilaç hazırlanması ve deneme amaçlı filler ortak özellik olarak ticari nitelikli olmayan, küçük çaplı daha ziyade bireysel nitelikteki eylemler olarak kendilerini göstermektedir. Bu eylemlere istisna tanınmasının arka planında eğitim, teknolojik ilerlemenin sağlanması, bireysel ihtiyaçların giderilmesi gibi etkenler rol oynamaktadır. Deneme amaçlı fillerin ticari nitelikli olabilecekleri yaklaşımı isabetli görülemez. Zira bu yaklaşım, hükmün kapsamını gerekçesine ve hükmün konuluş amacına aykırı şekilde genişletecek, aynı fikrada yer alan Bolar istisnasına ilişkin hükmü gereksiz ve anlamsız kılabilecek bir yaklaşım olacaktır.

SMK m. 85/3'de yer alan istisnalardan ilaç patenti koruması açısından en önemli olanı ise, şüphesiz Bolar istisnası olarak anılan ilaçların ruhsatlandırılması, bunun için gerekli test ve deneyleri de içine alan deneme amaçlı fillerdir. Eşdeğer ilaçların da orijinal ilaçlar gibi ruhsat prosedürüne tabi oldukları değerlendirildiğinde bu filller için patent süresinin sona ermesinin beklenilmesi gerekecektir. Söz konusu fillerin ve dolayısıyla ruhsat alma sürecinin uzunluğu değerlendirildiğinde ise, rekabetçi piyasanın oluşması gecikecek, bu durum kamunun aleyhine bir görünüm arzedecektir. Buna karşın, Bolar hükmü sayesinde, açılanan işlemler patent süresi içerisinde yapılabilmekte ve işaret edilen sakıncalar giderilmektedir. Türk hukukunda kabul edilen Bolar istisnası ruhsat işlemleri için gerekli test ve deneyleri kapsamaktadır. Seri üretim yapılması, depolama veya satışa sunulma gibi eylemler hükmün kapsamı dışındadır.

Bolar istisnasının diğer önemli veçhesi ise, veri imtiyazı üzerindeki etkisidir. Eşdeğer ilaçların patent süresini takiben derhal piyasaya arzı için önemli olan kısaltılmış ruhsat başvurusunda bulunabilme imkânı sayesinde, eşdeğer ilaç firmaları rekabetçi bir piyasanın oluşmasına katkı sağlamaktadır. Bolar istisnası aynı zamanda veri imtiyazı kapsamındaki test ve deneyleri kapsamakta olup Türkiye özelinde, uygulama ve yarg1 içtihatlarında da ortaya konulduğu üzere, ruhsat alınması dahil eşdeğer ilaçlara ilişkin bu tür fiiller patent hakkı ihlali, haksız rekabet gibi hukuka aykırılık yaptırımları ile karşılaşılmadan yürütülebilmektedir.

\section{Kisaltmalar}

$\mathrm{AB} \quad$ :Avrupa Birliği

ABD : :Amerika Birleşik Devletleri

Art. $\quad$ : Artikel

Bkz. : Bakınız

BGH : Bundesgerichtshof

BPatG : Bundes Patent Gericht 


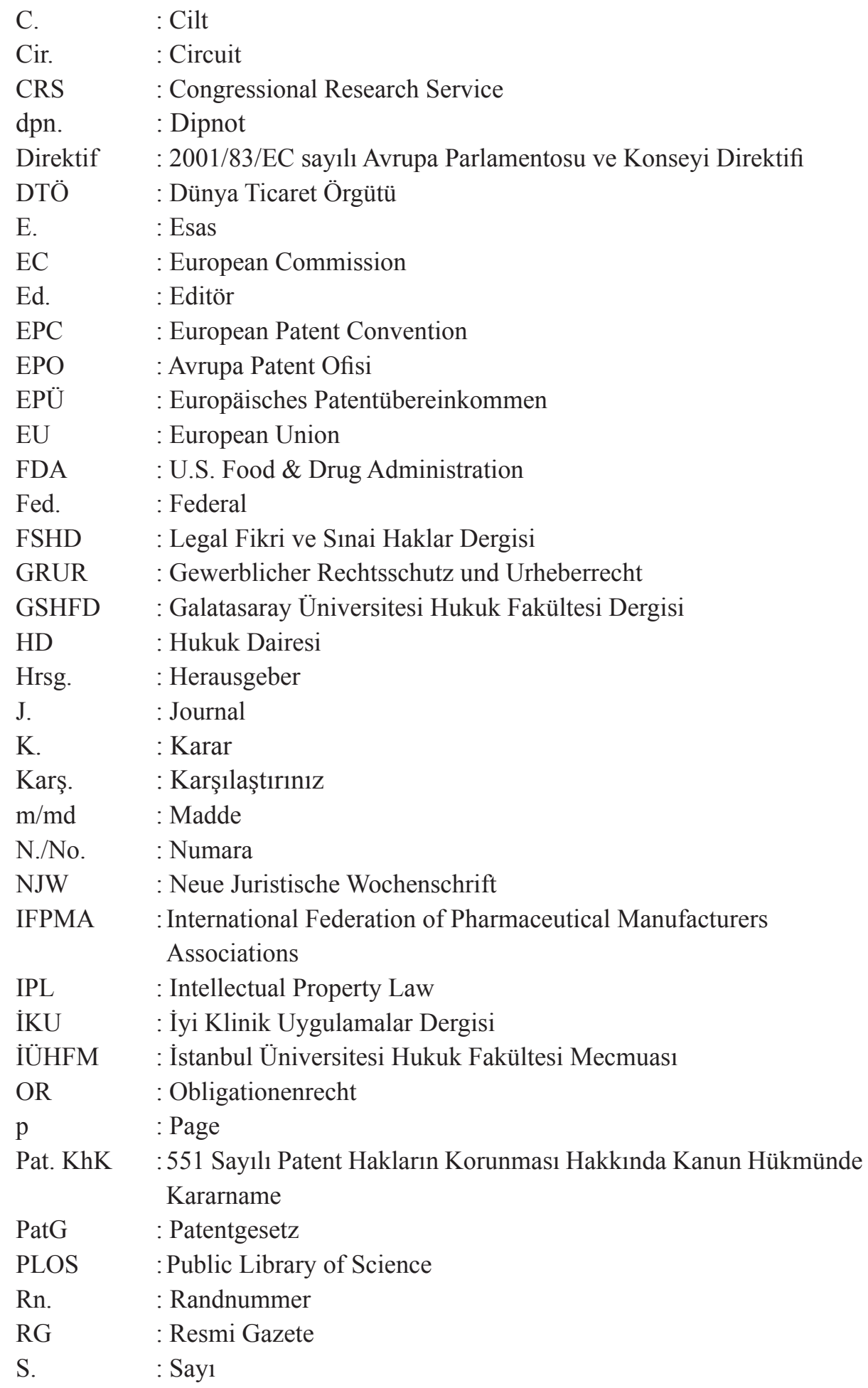




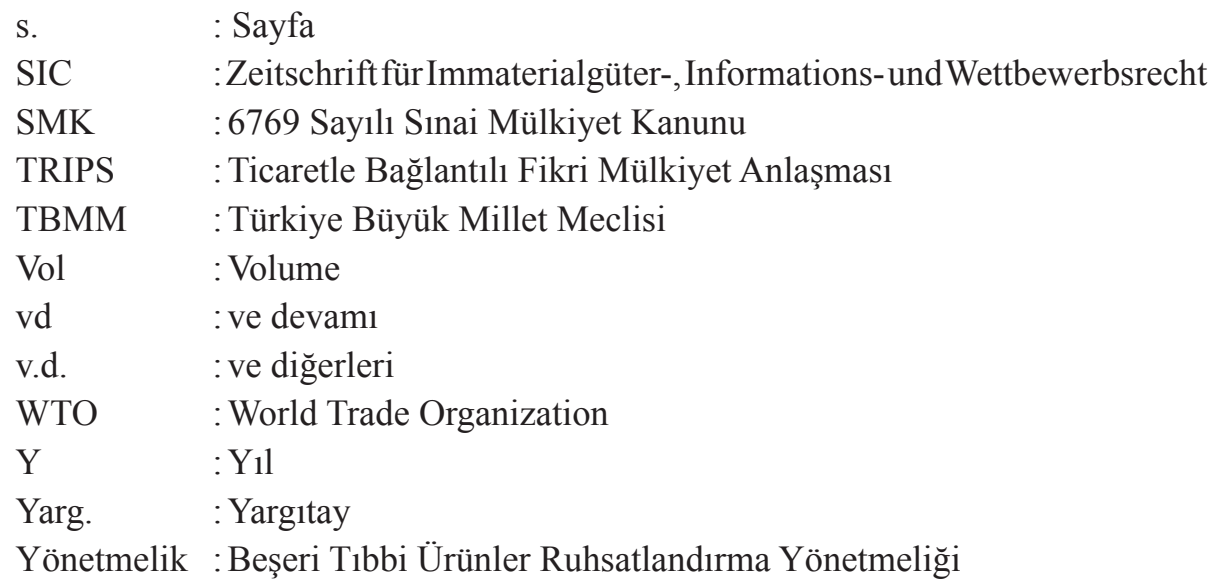




\section{Kaynakça/References}

Abbott, M. Frederick / Reichman, H. Jerome: "The DOHA Round's Public Health Legacy: Strategies For the Production and Diffusion of Patented Medicines under the Amended TRIPS Provisions", Journal of International Economic Law, C. 10, S. 4.

Ackermann, Markus: “Schütz ein Wirkstoffpatent vor “Prodrugs"?”, GRUR, Heft 8, 2018.

Aktaş, Yasemin: "Veri İmtiyazı Koruması ve Bolar İstisnasının Bu Koruma Üzerindeki Etkisi", FSHD, C. 13, S. 49, 2009.

Aslan, İ. Yılmaz /Şenyüz, Doğan/Ergün, Mevci: İşletme Hukuku, Bursa, 2005.

Aydıngöz, Selda Emre: "Ruhsatlandırma Öncesi ve Sonrası Klinik İlaç Araştırması Tasarımları", İKU Dergisi, S.15, S.15, 2006.

Ayiter, Nuşin: İhtira Hukuku, Ankara, 1968.

Baykara, Tamer / Çaylı, Hülya / Çelik, Hüseyin / Tokat, Mehmet / Ünalan, Turgay: Türkiye'de İlaçta Veri Koruması ve Uygulanmasının Mali Etkileri, Ankara, 2003.

Boldrin, Michele /Levine, David K.: Against Intellectual Property, Cambridge, 2008.

Bulut, Koray: İlaçlar ve Sinai Haklar, http://farmapatent.com.tr/docs/Ilaclar_Ve_Sinai_Haklar_ Koray_Bulut.pdf,(Son ErişimTarihi: 14.08.2018).

Correa, M. Carlos: "Pharmaceutical inventions: when is the granting of a patent justified?", Int. J. Intellectual Property Management, Vol. 1, No. 1/2, 2006, (Anılış: Granting of a Patent).

Correa, M. Carlos: Integrating Public Health Concerns into Patent Legislation in Developing Countries, Geneva, 2000, (Anılış: Integrating Public Health).

Çolak, Uğur: Kısaltılmış Ruhsat Başvurusundan Kaynaklanan Hukuki Uyuşmazlıklar ve Veri İmtiyazı Uygulaması, Fikri Mülkiyet Yıllığı, 2009.

Domeij, Bengt: Pharmaceutical Patents in Europe, Stockholm, 2000.

Düğer, Sırrı: Non-Patent Protection of Pharmaceuticals in Turkey, Aachen, 2012.

Esmond W. Robert/ Schwartzman, Robert A.: "The Patent Infringement Exemption Land Grab", Intellectual Property \& Law Journal, , Vol. 17, No. 6, 2005.

Garrison, Christopher: Exceptions to Patent Rights in Developing Countries, UNCTAD-ICTSD Project on IPRS and Sustainable Development, Geneva, 2006.

Güneş, İlhami: Sınai Mülkiyet Kanunu Işığında Uygulamalı Patent ve Faydalı Model Hukuku, Ankara, 2017.

Heinrich, Peter: PatG/EPÜ Schweizerisches Patentgesetz/Europäisches Patentübereinkommen Kommentar in synoptischer Darstellung, Zürich, 2010.

Hirsch, Ernst: Fikri ve Sinai Haklar, Ankara, 1948.

Iles, Kevin: A Comparative Analysis of the Impact of Experimental Use Exemptions in Patent Law on Incentives to Innovate, Northwestern Journal of Technology and Intellectual Property, Vol. 4, No. 1, 2005.

Işıklı, Hasibe: İlaçlarda Test ve Deney Verilerinin Korunması: Avrupa Birliği’nde Yeni Sistem, İktisadi Sektörler ve Koordinasyon Genel Müdürlüğü Hukuki Tedbirler ve Kurumsal Düzenlemeler Dairesi, Ankara, 2005.

İlter, Dilek: İlaçların Ruhsatlandırılması ve Piyasaya Sürülmesi Usulü, İlaç Hukuku, Erciyes Üniversitesi Hukuk Fakültesi I. Sağlık Hukuku Sempozyumu 08-09 Mayıs 2009, Ed. Murat Şen/Ahmet Başsözen, İstanbul, 2009.

İzgü, Enver: İlaç ve Patent, Ankara, 1992. 
Kaya, Arslan: Türk Hukukunda Patentten Doğan Haklar, IÜHFM, C. LV, S. 4, 1997, (Anılış: Patentten Doğan Haklar).

Kaya, Arslan: 551 Sayılı "Patent Haklarının Korunması Hakkında Kanun Hükmünde Kararname" ile Getirilen Zorunlu Lisans Sistemi, IÜHFM, C. LV, 1996, (Anılış: Hakkın Korunması).

Kayacan, Vildan: İlaçta Patent Korumasının Etkileri ve Korunma Tedbirleri, Ankara, 2001.

Kumar, K. Suresh / Tejswi, Aruna / Tejswi, Shikha: Patent Laws and Research Exemption imperatives - do scientists have enough freedom to operate?, Current Science, Vol. 99, No. 11, 2010.

Matthews, Duncan: "WTO Decision on Implementation of Paragraph 6 DOHA Declaration on the TRIPS Agreement and the Public Health: A Solution to the Access to Essential Medicines Problem?", Journal of International Economic Law, C. 7, S. 1.

Memiş, Tekin: İlaçların Patentlenmesi, İlaç Hukuku, Erciyes Üniversitesi Hukuk Fakültesi I. Sağlık Sempozyumu 08-09 Mayıs 2009, Ed. Murat Şen/Ahmet Başsözen, İstanbul, 2009, (Anılış: İlaçların Patentlenmesi).

Memiş, Tekin: Jenerik İlaçların Hukuki Konumu, Uluslararası Sağlık Hukuku Sempozyumu, Kadir Has Üniversitesi, İstanbul, 2008, (Anılış: Jenerik İlaç).

Mes, Peter: Patentgesetz Gebrauchsmustergesetz, 4. Auflage, 2015.

Mukherjee, Santanu: Markush Claims, Guide to Pharmaceutical Patents, Vol. II, Ed. M. Carlos Correa, Geneva, 2008.

Mukherjee, Santanu: Enabling Disclosure, Guide to Pharmaceutical Patents, Vol. II, Ed. M. Carlos Correa, Geneva, 2008.

Noor, Marjan / Smith, Camilla: EU Strikes Balance With New Bolar Provision, Managing Intellectual Property, London, 2005.

Noyan, Erdal: Patent Hukuku, 3. Bask1, Ankara, 2015.

Odman, Ayşe Boztosun: İlaçta Zorunlu Lisans Uygulamaları, İlaç Hukuku, Erciyes Üniversitesi Hukuk Fakültesi I. Sağlik Hukuku Sempozyumu 08-09 Mayıs 2009, Ed. Murat Şen/Ahmet Başözen, İstanbul, 2009.

Odman, Ayşe N.: Fikri Mülkiyet Hukuku ile Rekabet Hukukunun Teknolojik Yeniliklerin Teşvikindeki Rolü, Ankara, 2002.

Ortan, Ali Necip: Patent Lisans Sözleşmesi, Ankara, 1979, (Anılış: Patent Lisans1).

Özcan Büyüktanır, Burcu G.: Türk Hukukunda İlaç Patentine Genel Bir Bakış, Hacettepe Hukuk Fakültesi Dergisi, S. 2, C. 2, 2012.

Rigamonti, Cyrill P.: Die Schweiz und das materielle Recht der Patentverletzung in Europa, SIC!, S. 4, 2014.

Rogge, Rüdiger/Kobber-Dehm, Helga: Benkard PatG: PatG Gebrauchsmustergesetz, Patentkostengesetz, 11. Auflage, 2015.

Saraç, Tahir: Patentten Doğan Hakka Tecavüz ve Hakkın Korunması, Ankara, 2003.

Schacht, Wendy H., Thomas, John R.: Patent Law and Its Application to the Pharmaceutical Industry: An Examination of the Drug Price Competition and Patent Term, Restoration Act of 1984 ("The Hatch-Waxman Act"), CRS Report for Congress, CRS Web Order Code RL30756, 2005, https://fas.org, (Son Erişim Tarihi: 12.09.2018).

Scharen, Uwe: Benkard Patentgesetz: PatG Gebrauchsmustergesetz, Patentkostengesetz, 11. Auflage, München, 2015.

Scherer, F. M. /Jayashree, Watal: "Post-TRIPS Options for Access Patented Medicines in Developing Nations”, Journal of International Economic Law, C. 5, S. 4, 2002. 
Sezgin Huysal, Ayșegül: İlaç Patenti, İstanbul, 2010.

Suluk, Cahit: “Türkiye'de İlaçların Patent ve Diğer Fikri Mülkiyet Hakları ile Korunması", Terazi Hukuk Dergisi, C. 9, S. 100, 2014.

Suluk, Cahit/Karasu, Rauf/Nal, Temel: Fikri Mülkiyet Hukuku, Ankara, 2018.

Tekinalp, Ünal: Fikri Mülkiyet Hukuku, İstanbul, 2012.

Tekinalp Ünal/Çamoğlu, Ersin: Sınai Mülkiyet Kanunu, İstanbul, 2017.

Tetzner, Volkmar: "Patentverletzung durch Forschung”, GRUR, Heft 11, 1966.

Thomas, John R.: Scientific Research and the Experimental Use Privilege in Patent Law, CRS Report for Congress, CRS Web Order Code RL32651, 28.02.2004, https://fas.org/sgp/crs/ RL32651.pdf, (Son Erişim Tarihi: 12.09.2018).

Timmermans, Karin: Monopolizing Clinical Trial Data: Implications and Trends, PLOS Medicine, https://journals.plos.org, Volume 4, Issue 2, 2007, (Son Erişim Tarihi: 10.09.2018).

Uğurluoğlu, Özgür: “İlaç Sektöründe Fikri Mülkiyet Koruması”, Hacettepe Sağlık İdaresi Dergisi, C.17, S. I, 2014.

Upadhye, Shashank: Generic Pharmaceutical Patent and FDA Law, U.S.A., 2008.

Veron, Pierre: Doctrine of Equivalents, Cambridge, 2001.

Yalçıner, Uğur G.: İlaç ve Patent, Türkiye'de ve Dünyada Son Gelişmeler, Ankara Barosu Fikri Mülkiyet ve Rekabet Hukuku Dergisi, C. 2, S. 3, 2002, (Anılış: İlaç ve Patent).

Yalçıner, Uğur: Türkiye'de İlaçta Patentin Bugünü ve Yarını, Ankara Barosu Uluslararası Hukuk Kurultayı 2002, Ankara, 2002, (Anılıș: Kurultay).

Yasaman, Hamdi: Fikri ve Sınai Mülkiyet Hukuku (Fikir ve Sanat Eserleri Endüstriyel Tasarımlar Patentler İle İlgili Makaleler Hukuki Mütalâalar Bilirkişi Raporları), İstanbul, 2006.

Yıldırım, Murat: "İlaç Patentlerinde İstemlerin Yorumlanması", Ankara Barosu Fikri Mülkiyet Hukuku Dergisi, 2006, C. 6, S. 2.

Yusufoğlu, Fülürya: Patent Verilebilirlik Şartları, İstanbul, 2014, (Anılış: Patent).

Yusufoğlu, Fülürya: "Jenerik İlaç ve Jenerik İlaç Ruhsat Başvurusunun Patente Tecavüz Çerçevesinde Değerlendirilmesi”, GSHFD, C. 2, S. 2, 2014, (Anılış: Jenerik İlaç).

Zenhäusern, Urs: Vertragsverhältnisse Teil 1: Innominatkontrakte, Kauf, Tausch, Schenkung, Miete, Leihe, Handkommentar zum Schweizer Privatrecht Art. 184 - 318 OR, Hrsg. Markus Müller-Chen, Claire Huguenin, Zürich, 2016.

\section{Yazarı Olmayan Kaynaklar/Non-Author References}

„Amlodipin“ Obergericht Thurgau vom 7. April 2005 (Massnahmeentscheid), SIC!, S.4., 2006.

Avrupa Eşdeğer İlaç Birliği, 13. Yıllık Konferans Bilgi Notu, http://www.ieis.org.tr (Son Erişim Tarihi: 14.09.2018).

BGH Patentrechtliches Versuchsprivileg - Klinische Versuche II, NJW, Heft 46, 1997.

BGH: BGH 11.07.1995 X ZR 99/92 „Klinische Versuche“, GRUR, Heft 1, 1996.

Botschaft zur Änderung des Patentgesetzes und zum Bundesbeschluss über die Genehmigung des Patentrechtsvertrags und der Ausführungsordnung vom 23. November 2005.

BPatG: Zwangslizenz für Herstellung eines HIV-Medikaments - Isentress, GRUR, S. 4, 2017.

European Patent Decisions Report, BGH of 22.02.2000- Positionierungsverfahren (XZR 111/98), Munich, 2004. 
EPO, Guidelines for Examination in the European Patent Office, Munich, 2009. http://mevzuat.shgm.gov.tr/, (Son Erişim Tarihi: 01.08.2018).

International Federation of Pharmaceutical Manufacturers Associations, Encouragement of New Clinical Drug Development: The Role of Data Exclusivity, Geneva, 2000.

İlaç Patenti Tecavüzüne İlişkin Venlafaksin Kararı, http://fikrimülkiyetplatformu.org, (Son Erişim Tarihi: 16.09.2018).

Klinische Versuche 1, [1997] R.P.C 623.

Pharmaceuticals Policy and Law, Vol. 11, No.4, 2009, s. 523-557.

Roche Products, Inc. Appellant, v. Bolar Pharmaceutical Co., Inc., Appellee, 733 F.2d 858 (Fed. Cir. 1984) https://law.justia.com, (Son Erişim Tarihi: 12.09.2018).

733 F.2d 858 (Fed. Cir. 1984).

26.04.2004 tarih, 1/740 E. ve 51 K. no'lu TBMM Adalet Komisyonu Raporu, https://www. tbmm.gov.tr/tutanaklar/, (Son Erişim Tarihi: 08.01.2019). 